\title{
Neandertal camps and hyena dens. Living floor 150A at Grotta dei Santi (Monte Argentario, Tuscany, Italy)
}

This is the peer reviewed version of the following article:

Original:

Spagnolo, V., Crezzini, J., Marciani, G., Capecchi, G., Arrighi, S., Aureli, D., et al. (2020). Neandertal camps and hyena dens. Living floor 150A at Grotta dei Santi (Monte Argentario, Tuscany, Italy). JOURNAL OF ARCHAEOLOGICAL SCIENCE: REPORTS, 30 [10.1016/j.jasrep.2020.102249].

Availability:

This version is availablehttp://hdl.handle.net/11365/1106591

since 2020-11-30T11:57:38Z

Published:

DOI:10.1016/j.jasrep.2020.102249

Terms of use:

Open Access

The terms and conditions for the reuse of this version of the manuscript are specified in the publishing policy. Works made available under a Creative Commons license can be used according to the terms and conditions of said license.

For all terms of use and more information see the publisher's website.

(Article begins on next page) 
- A Mousterian living floor is analysed with a spatial and interdisciplinary approach

- A complex processual history was reconstructed by a taphonomic perspective

- A brief hyena den shortly preceded the structured Neandertals camp

- Faunal processing, lithic production and shell-related activity were found

- Multipurpose hearth-related activity areas were found 


\title{
Neandertal camps and hyena dens. Living floor 150A at Grotta dei Santi (Monte Argentario, Tuscany, Italy)
}

Vincenzo Spagnolo ${ }^{\mathrm{a}, \mathrm{b}}$ vincenzo.spagnolo@unisi.it; Jacopo Crezzini ${ }^{\mathrm{a}, \mathrm{b}}$ jacopocrezzini@gmail.com; Giulia Marciani ${ }^{\mathrm{a}, \mathrm{c}}$ giuliamarciani@hotmail.it; Giulia Capecchia, b capecchigiulia@,alice.it; Simona Arrighi $^{\mathrm{a}, \mathrm{b}, \mathrm{c}}$ S.arrighi@hotmail.com; Daniele Aurelia, b, e danieleaureli1@gmail.com; Isak Ekbergg isak.e.ekberg@gmail.com; Sem Scaramucci ${ }^{\mathrm{a}, \mathrm{b}}$ semscara@yahoo.it; Laura Tassoni ${ }^{\mathrm{d}}$ laura.tassoni@student.unife.it; Francesco Boschin ${ }^{\mathrm{a}, \mathrm{b}}$ fboschin@hotmail.com; Adriana Moroni ${ }^{\mathrm{a}, \mathrm{b}, \mathrm{f}}$ adriana.moroni@unisi.it.

a. Dipartimento di Scienze Fisiche, della Terra e dell'Ambiente, Unità di Ricerca di Preistoria e Antropologia, Università degli Studi di Siena (UniSI) - Strada Laterina, 8, 53100, Siena, Italy; b. Centro Studi sul Quaternario Onlus - Via Nuova dell'Ammazzatoio, 7, 52037, Sansepolcro (AR), Italy.

c. Department of Cultural Heritage, Università di Bologna (UniBO) - Via degli Ariani, 1, 48121, Ravenna, Italy;

d. Dipartimento di Studi Umanistici, Sezione di Scienze Preistoriche e Antropologiche, Università degli Studi di Ferrara (UniFE) - C.so Ercole I d'Este, 32, 44100, Ferrara, Italy.

e. UMR 7041 ArScAn équipe AnTET.MAE, Université Paris Ouest Nanterre La Défense (UPN) 21, Allée de 1’Université, F-92023, Paris, France;

f. Istituto Italiano di Paleontologia Umana - Anagni - Italy.

g. Institutionen för arkeologi och antikens historia, Lunds Universitet, Lund, Sweden.

\begin{abstract}
:
Grotta dei Santi represents a very suitable investigation field for carrying out an inquiry into the Neandertal behaviour at a high-resolution time scale, in order to obtain data useful for the "functional" reading of the economic and settling strategies. This cave opens into the Monte Argentario Promontory (southern coast of Tuscany, central Italy), almost at sea-level, at the base of a limestone falaise about $50 \mathrm{~m}$ high. During MIS 3, when Neandertals occupied the site, there was a wide plain in front of the cave. Excavations carried out by the University of Siena over the last 11 years brought to light several Mousterian occupation phases represented, most of the times, by thin living floors separated from one another by sterile sediments. However, another "occupant", the spotted hyena (Crocuta crocuta), left clear traces in the cave in layers other than those occupied by
\end{abstract}


humans. Although there usually is a clear-cut stratigraphic separation, a partial overlapping between the human and hyena occupations is sometimes documented, owing to their closeness in time. This is the case for the uppermost "living floor" of layer 150, which is the object of our study. A multidisciplinary integrated analytic methodology was applied, including lithic technology, taxonomic analysis of faunal remains, taphonomy, use-wear analysis and spatial analysis by means of a GIS platform. This approach allowed us to detect a set of parameters useful for identifying activities due to each of these two predators individually, which provided substantial information about their behaviours.

Key words: Neandertal behaviour; Crocuta crocuta; Taphonomy; Lithic technology; GIS; Activity Areas; MIS 3. 


\section{Introduction}

The increasing attention for problems related to the reconstruction of Neandertals' behaviour has pushed research more and more towards analytical approaches and archaeological contexts characterized by high temporal resolution. The discrepancy between anthropogenic and geological times in the formation of archaeological "layers" constitutes the main node of the palimpsest-effect debate since the '80s (Bailey, 2007 and references therein; Romagnoli et al. 2018). Over the last decade, several studies have been aiming at developing increasingly integrated analytical procedures to "dissect" the palimpsests into "smaller time-units", increasing the time-resolution (e.g. Bargalló et al., 2016; Henry, 2012; Leierer et al. 2019; Machado et al., 2013; Machado and Pérez, 2016; Martínez-Moreno et al., 2016; Real et al., 2018; Romagnoli and Vaquero, 2016; Rosell et al., 2012; Spagnolo et al., 2016a, accepted; Thacher et al., 2017; Vaquero, 2008; Vaquero et al., 2012, 2017; Villaverde et al., 2017; Way, 2018). Indeed the availability of contexts whose duration is as akin as possible to the human time-scale rather than the geological one, is a fundamental prerequisite for a realistic reading of some economic and social structures which are behind the evolution of settlement dynamics. Moreover, the high-temporal resolution issue has played a major role in addressing research on Palaeolithic sites where short-lived contexts are present, due to the interaction of various causes (e.g. fortuitousness, site function, sedimentation rates/occupation intensity, "catastrophic" events). From an analytical point of view, these contexts should be considered and treated as "short-term palimpsests" lato sensu. Following the time-perspectivism approach (Bailey, 2007), each sort of anthropogenic context is definitively a palimpsest made by the overlapping of different kind of activities, functions, times, and/or meanings. The time-span-based differentiation between short-lived and long-lived palimpsests is essential in order to correctly address the research, because different cultural phenomena can be identified (or missed) at different time-scales (intended as time-span/resolution). In this light, the concept of "living floor" is not antithetical to that of palimpsest (e.g. a palimpsest-free context), but it should be described as a geometrically-defined sub-set of the short-lived palimpsests, including the very thin (few $\mathrm{mm}$ ) anthropogenic layers sandwiched between sterile layers. The specific stratigraphic characteristics of living-floors allow us to perform some high temporal resolution analyses, potentially increasing our understanding of the formation processes and relationships among the different sorts of findings. However, also in the short-lived cases the formation processes of the archaeological contexts can dramatically affect the preservation and visibility degree of the archaeological records. Close alternation between humans and other carnivores, for instance, can represent a significant obstacle for the correct interpretation of the records (Bountalis and Kuhn, 2014; Camarós et al., 2013, 2017; Daujeard et al. 2016; Diedrich, 2011; Esteban-Nadal, 2012; Kuhn, 2014). On the other hand, sites with living-floors and/or other sort of short-term palimpsests, where different "bone accumulators" 
are present, embody a very suitable frame of reference for developing efficient analytical protocols aimed to disentangle the human and natural components of the Stratigraphic Units (e.g. Conti et al., 2012; Crezzini et al., 2016; Enloe, 2012; Moroni et al., 2019; Rusch et al. 2019; Sanchis et al., 2019). Moreover, in the scientific literature, several scholars have paid attention to the archaeological meaning of carnivores in action, approaching this issue by means of actualistic/taphonomic methods, both from an extant and an archaeological standpoint, sometimes also taking into account the spatial variable. Most of these works are focused on the spotted hyena (Crocuta crocuta), as this predator is the main bone-accumulator contending with humans for caves and shelters (e.g. Arribas and Palmqvist, 1998; Binford et al., 1988; Crezzini et al., 2016; Diedrich, 2010, 2011; Fourvel, 2012; Potts et al., 1988; Rusch et al., 2019; Saladié et al., 2017; Sanchis et al., 2019). Other studies involve the ethological and taphonomic analysis of other boneaccumulators/modifiers, such as the leopard (Ruiter and Berger, 2000; Sauqué and Sanchis, 2017), red fox (Krajcarz and Krajcarz, 2014), bear (Camarós et al., 2013, 2017; Rosell et al., 2019) and badger (e.g. Roper et al., 1991). 


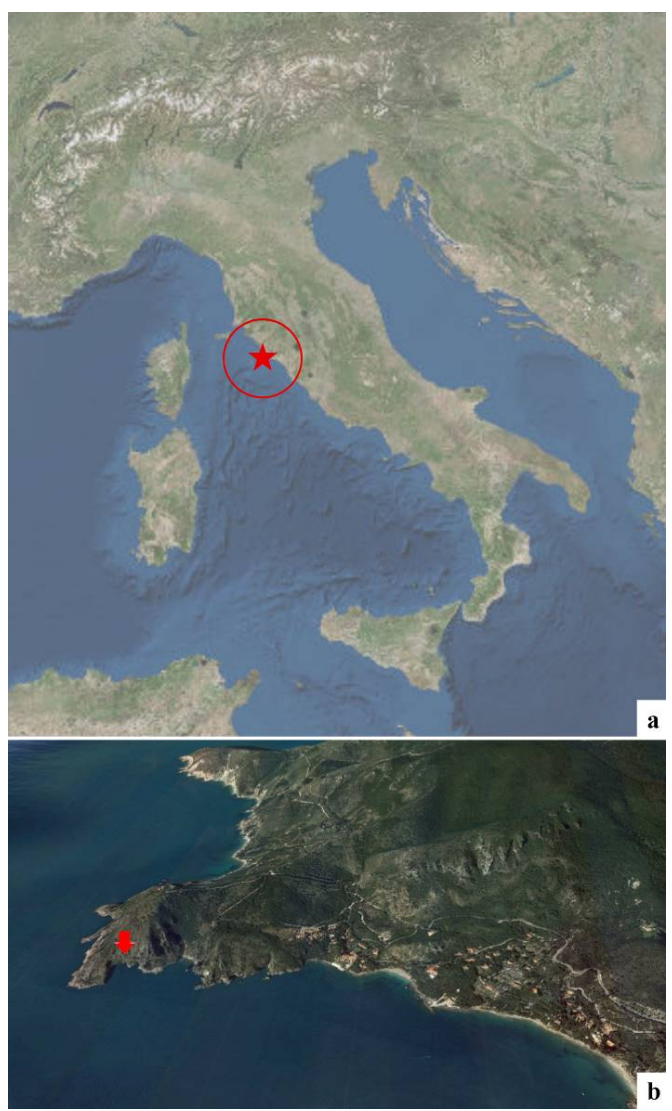

Fig. 1. Site location: (a) on the photomap of Italy (source: ESRI World Basemap) and (b) on the Mt. Argentario Promontory (source: Google Earth).

The aim of this paper is to lay groundwork for a wider analytical project focused on the creation of a multifocal taphonomic frame of reference for characterizing material signals derived from the activities of the spotted hyena and humans in Pleistocene contexts. Grotta dei Santi (Monte Argentario, Tuscany, Central Italy) (Fig. 1) is particularly suitable for this purpose as its MIS 3 stratigraphic sequence contains several living floors and other short-term palimpsests, which are usually separated by sterile clay/sandy layers. Different occupation patterns (Crocuta crocuta alone, close alternation between humans and hyena, Neandertals alone) occurred in similar sedimentological and paleo-environmental conditions, which developed in a relatively brief chronological span (Moroni et al., 2019). This is an ideal context both for carrying out highresolution studies and for obtaining reliable interpretations of data and reconstructive models. Prospectively, the comparative analysis of results from all the layers of Grotta dei Santi will 
significantly contribute to creating a large sample-based taphonomic framework, also usable as a benchmark for other sites having superimpositions between humans and hyenas.

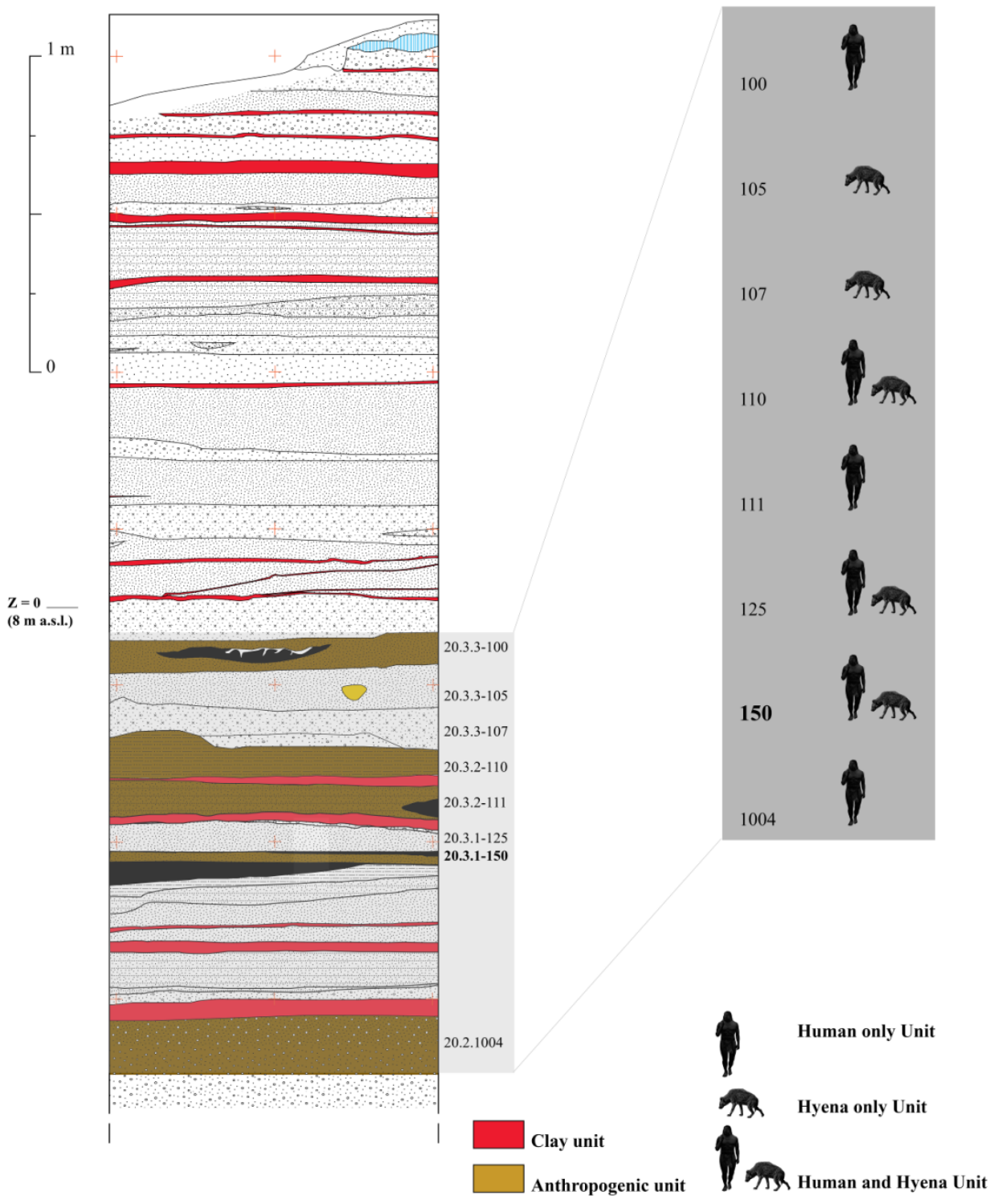

Fig. 2. Stratigraphic sketch of the excavated deposit and correlation between Units and the relative occupation patterns. 
The context here analysed is the uppermost living floor of Unit 20.3.1-150 (Fig. 2). Our multidisciplinary approach includes the taxonomic, anatomical and taphonomic analyses of both macro-faunal and mollusc remains, the technological and use-wear analyses of the lithic finds and the spatial analysis of the aforementioned data. Our results appear particularly encouraging, as the relative "weight" of the components of the spotted hyena and humans can be clearly discriminated. The human occupation was shown to prevail and to come after the Crocuta crocuta. This can allow us to reconstruct some aspects of the functional structure of the Neandertal camp.

\section{The context}

Grotta dei Santi is a roughly rectangular wide cavity directly facing the sea and opening into the "Calcare Cavernoso" formation on the slopes of the Monte Argentario Promontory. The internal cave deposit (about $3 \mathrm{~m}$ thick) is composed of an upper part devoid of any anthropogenic evidence and a lower part (at least $1.5 \mathrm{~m}$ thick) containing stratified, usually thin, layers with Neandertal and/or hyena occupations alternating with sterile sediments. While at the rear of the cave the deposit is preserved, its front (towards the entrance) has been completely removed by the sea, thus leaving the profile of the stratigraphic sequence exposed from top to bottom. Fieldwork at Grotta dei Santi, carried out by the University of Siena, was firstly (2007-2014 fieldwork seasons) devoted to remove the reworked sediments due to the Holocene erosive events. Later on, research was dedicated to understanding the chrono-cultural succession of the cave deposit (Moroni et al., 2019) (Fig. 2). Data presented here are intended to give a preliminary overview on the site informative potentialities, taking the portion excavated in 2014 (about $4 \mathrm{~m}^{2}$ ) of Unit 20.3.1-150 upper living floor (150A), as an example.

The radiocarbon (on charcoal) and OSL chronological model obtained at the Max Planck Institute for Evolutionary Anthropology of Leipzig places the whole anthropogenic sequence of Grotta dei Santi in the time span between 50 and $40 \mathrm{ka}$ BP (detailed information about the cave infill formation processes and chronology can be found in Moroni et al., 2019). Typical marks of the Units exclusively occupied by carnivores are large quantities of both entire and trampled coprolites (which often create actual thin levels), combined with scant fragments of bones of prey (with chewing or digestion traces) and very rare bones of predators (including Crocuta Crocuta, Panthera pardus and Vulpes vulpes) (Moroni et al., 2019). 


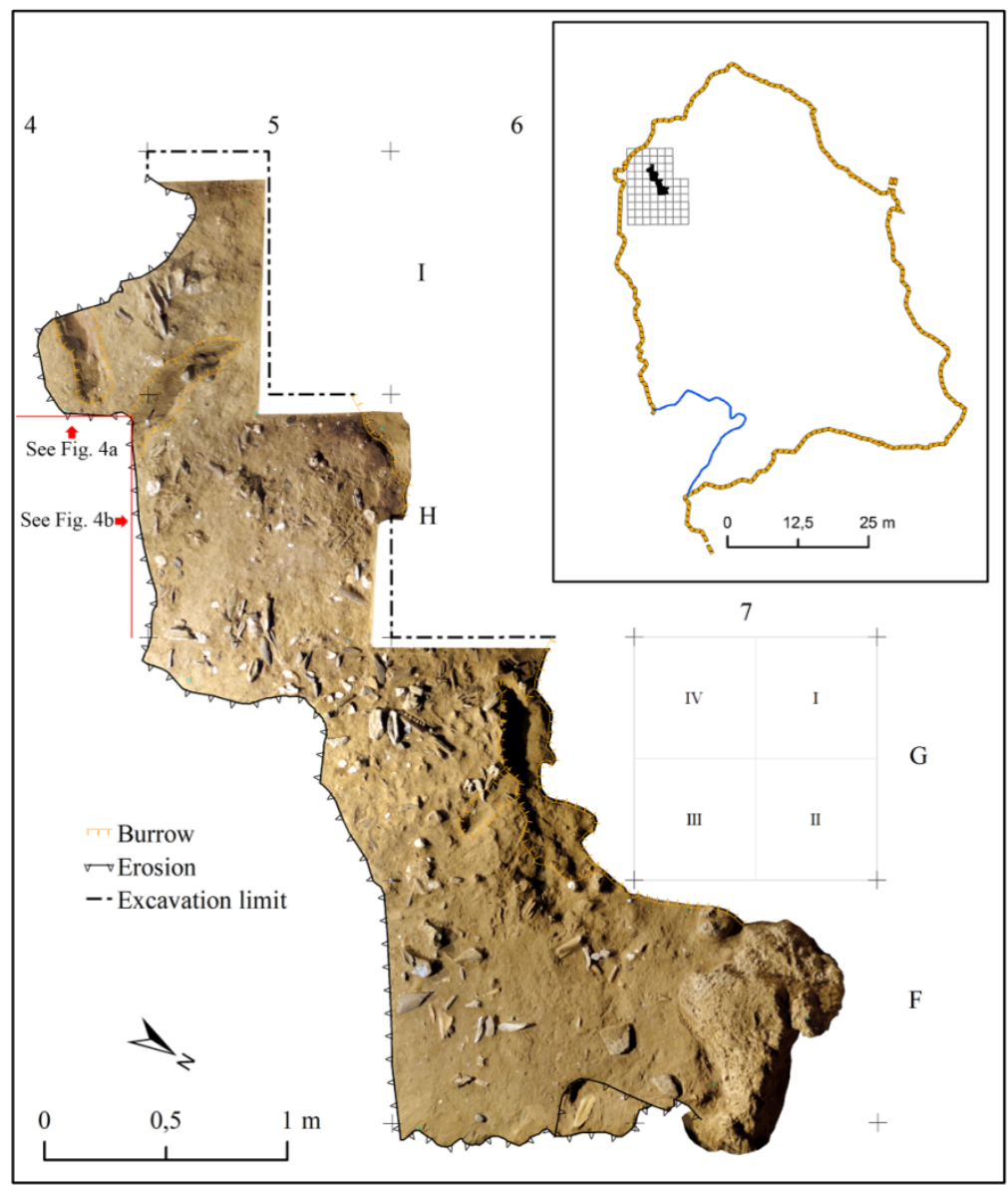

Fig. 3. Accurate photomap of the investigated surface of the living floor $150 \mathrm{~A}$ and location of the excavation grid into the cave.

The top of Unit 20.3.1-150 (hereafter 150) was brought to light during the field season 2014, over a surface of $4 \mathrm{~m}^{2}$ (Fig. 3). This Unit is formed by at least three living floors (few mm thick) separated by levels of sterile sand (Fig. 4). The excavation was carried out adopting a $1 \times 1 \mathrm{~m}$ regular grid, subdivided into $0.5 \times 0.5 \mathrm{~m}$ sectors (Fig. 3). The uppermost human occupation (150A) contains a fireplace and several clusters of remains of anthropogenic origin. Along its E-NE side this living floor was truncated by the Holocene erosion. In addition, relevant bioturbations, including a wide burrow/channel, partly altered other sectors of the excavated area. The rest of the exposed living floor was found to be in an exceptional state of preservation (Fig. 3). 

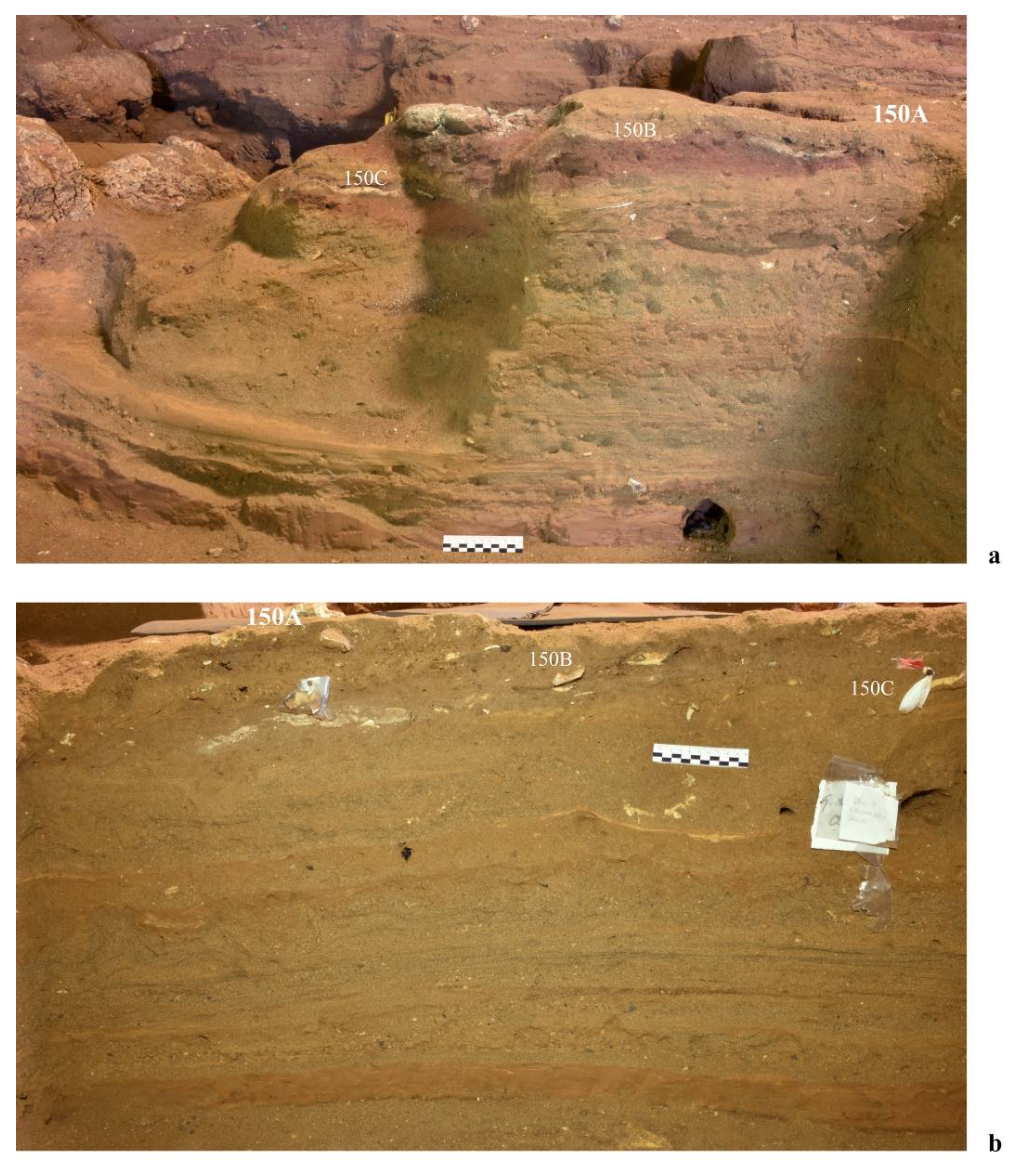

Fig. 4. Photographic detail of Unit 150 along the cross-sections H/I-4 (a) and 4/5-H (b). See Fig. 3 for the relative position of the sections.

\section{Materials and methods}

The study of $150 \mathrm{~A}$ was carried out with a multidisciplinary integrated analytical protocol, including the zooarchaeological (taxonomy and taphonomy), lithic (technology and traceology), malacological (taxonomy and taphonomy) and spatial analyses (taphonomy and reconstruction of the activity areas).

\subsection{Zooarchaeological analysis}


Taxonomic and skeletal identification of macromammals was based on the reference collections from the Research Unit of Anthropology and Prehistory of the University of Siena. Species abundance was quantified using the Number of Identified Specimens (NISP; Grayson, 1984) and the Minimal Number of Individuals (MNI; Chaplin, 1971). All specimens were divided into dimensional (1-3 cm, 3-6 cm, 6-10 cm, >10 cm) and anatomical categories (i.e. "skull”, "jaw”, "teeth", "vertebrae”, "ribs”, or more generically “epiphysis”, “diaphysis”, “spongy bones”). Fragments of cancellous bone and bone fragments which could not be assigned to a specific category were gathered into the class: "others". This procedure allowed us to assess the degree of fragmentation of bones. Specimens showing fresh fractures produced during their recovery were excluded from this count. The fact that the bones were well preserved permitted a detailed analysis of bone surface modifications. Fresh or dry status of diaphyses at the moment of breakage was estimated using the Fracture Fresh Index (FFI; Outram, 2002).

\subsection{Lithic analysis}

\subsubsection{Technology}

The lithic sample of living floor 150A consists of 116 items in a good state of preservation and with fresh edges. In order to gain a complete picture of the production procedure the technological study was carried out (Boëda, 1994; Geneste, 1991; Inizan et al., 1999), registering all the pieces' morpho-technical characters in an Access ${ }^{\circledR}$ database (Marciani, 2018). The traits collected for each piece include the lithotype (chert, jasper, siliceous limestone, quartz) the granulometry (fine or coarse grained), and geological nature (pebble, slab, block). For the metrical quantification we considered 5 dimensional classes (DC) evaluated on the area covered by each piece on a millimeter graph paper (Marciani et al., 2016; Spagnolo, et al., 2016a) (DC 1: 1-50 mm², DC 2: 50-100 mm², DC 3: $100-150 \mathrm{~mm}^{2}$, DC 4: 150-200 $\mathrm{mm}^{2}$, DC 5:>200 $\mathrm{mm}^{2}$ ). Items larger than the second DC were also measured (length, width, thickness) according to their technological axes. When the orientation was not possible, the longest measure was conventionally regarded as the length. The definition of flakes, long flakes or blades is based on the ratio length/width (ratio between 0 and $1.5=$ flake; ratio between 1.5 and $2=$ long flake; more than 2 = blade), according to Laplace (1968). Then we considered the integrity degree of the item and the location of fractures in the case of broken pieces. The retouched tools were described according to Laplace (1964).

A preliminary evaluation of the presence and location of macro-traces was made by naked eye and with a magnifying glass (based on the recurrence, order and regularity of the scars, see next paragraph for specific study in the attribution of these traces). 
All the artifacts were sorted according to the following technological classes: pebbles, hammerstones, flakes, cores, micro-flakes (intact flakes of the 1-2 DC), debris (fragmented or altered items of the 1-2-3 DC), undetermined (fragmented or altered items larger than the 4 DC whose orientation is not possible). Flakes were analyzed considering their role in the reduction sequence; thus their technological category are: completely-cortical flakes (100\% cortical); semi-cortical flakes (between 100-75\% of cortex coverage); management flakes (flakes produced when regulating the lateral and distal convexities and angles of the core with less than $75 \%$ of cortex; and flakes aimed at managing the striking platform); target flakes (the predetermined objectives of the debitage). In this case we considered as objectives of debitage: long baked target flakes (a blank with at least one cutting edge opposed to a back, cortical or created by flaking (Bordes, 1961); convergent target flakes; long target flakes. A peculiar technological category is the pseudo-Levallois point, this type of flake can be a target object of a reduction sequence (e.g. discoid production), or a management flake in another context (e.g. centripetal Levallois). The function of this type of flake can be ascertained only on the basis of the context in which it is found, and in this case, we cannot ascertain its role.

For each flake we recorded extension $(0 ; 0-25 \% ; 25-50 \% ; 50-75 \% ; 75-100 \% ; 100 \%)$ and position of cortex (lateral, backed side, proximal, distal, mesial) morphology, symmetry - according to the technological axis - section shape, presence of flaking accidents. A diacritical analysis was performed in order to identify the direction and chronological order of the scars and their role in the debitage process (Dauvois, 1976; Inizan et al., 1999). Percussion attributes including type of butt, position of the impact point, and type of bulb were taken into consideration. According to these technical and morpho-metrical features the volumetric concept of debitage has been identified for each flake: Levallois (unipolar or centripetal); additional debitage (i.e. volumetric unidirectional production without management of convexities. e.g. Boëda, 1997, 2013; Guilbaud and Carpentier, 1995).

For each core we considered: the type and morphology of the raw block; its volumetric conception of exploitation (Boëda, 2013); the hierarchy of surfaces; the striking platform type (partial, peripheral), position (unipolar, bipolar, orthogonal) and mode of organization (one or several detachment, with or without abrasion of the overhang, without any preparation); the diacritical analysis of scars (including number, direction chronology and role of each scar) (Dauvois, 1976; Inizan et al., 1999) and the reasons why the core was abandoned (cf. Marciani, 2013, 2018). Moreover, to integrate the spatial and technological studies some lithic traits (significant to infer insights on spatial taphonomy of the context and human behavior) were selected, including both the Dimensional Classes and the lithic technology. As far as the lithic technology is concerned, the sample was sorted in macro-categories, including: production waste (all the completely-cortical, 
semi-cortical, management flakes, flakes aimed at managing the striking platform, undetermined, micro-flakes and debris), target flakes (without macro-traces on the edges), tools (all the retouched items and the flakes with micro-traces on the edges), cores and hammer-stones/pebbles. The sub-set of the production waste included into the smallest Dimensional Class (all the items $<50 \mathrm{~mm}^{2}$ ) was taken into account as micro-debris. These categories were conceptualized following the criteria described in Spagnolo et al. (2016a, 2019).

\subsubsection{Traceology}

A preliminary test to evaluate the feasibility of use-wear analysis was carried out on a sample of 11 lithic tools randomly selected from the technological categories of semi-cortical, completely cortical flakes and target objects, plus the pseudo Levallois point. The cortical items were chosen in order to test the functional potential of the cortical portion of the flakes. The target objects were selected because of their role of objectives of the debitage. The pseudo Levallois point was added to the sample because of the presence of clear macro-traces.

Use-wear analysis was carried out by means of both low-power approach (LPA) (Tringham et al., 1974; Odell, 1980) and high-power approach (HPA) (Keeley, 1980; Van Gijn, 1990). In both cases observations were made by the 3D digital Hirox KH 7700 microscope: for LPA analysis (20x-80x magnifications) this device was equipped with a MX-G 5040Z body and an AD-5040Lows lens, for HPA examinations (140x-560x magnifications) with an MXG-10C body and OL 140 II lens (Arrighi and Borgia 2009; Sano et al. 2019; Wierer et al., 2018). Traces on the archaeological lithic tools were interpreted by means of comparison with the experimental reference collection of the Research Unit "Prehistory and Anthropology" of the University of Siena.

\subsection{Malacological analysis}

For the taxonomic analysis of the malacofaunal sample we used the updated nomenclature from two online datasets: the S.I.M. - Società Italiana di Malacologia (www.societaitalianadimalacologia.it) and the WoRMS - World Register of Marine Species (www.marinespecies.org). The quantification indexes adopted include the Number of remains (Nr), the Number of Identified Specimens (NISP), the Minimum Number of Individuals (MNI) for the gastropods and the Minimum Number of Valves (MNV) for the bivalves. MNV is aimed to better represent each valve (that is a unitary datum), highlighting the laterality of each remain. MNI and MNV have been calculated by means of landmarks, following Gutiérrez-Zugasti (2011). The correlation of the identified species with specific habitats was made following Santhanam (2018a, b).

The taphonomic analysis was performed on the NISP following Claassen (1998), taking into account the pre-depositional alterations (e.g. marine abrasion, predation by other molluscs and 
bioerosion), the intentional/unintentional anthropogenic alterations (e.g. thermic alteration, transformation of the edges and use as tools) and the post-depositional transformations (e.g. fragmentation, abrasions, root marks, carbonate/sediment crusts, decalcification).

\subsection{Spatial analysis}

The archaeological visibility of a context (sensu Spagnolo et al., 2019) expresses its actual overall potential (then also the relative error margin) to be correctly referred to the behavioural, social and economic structures that produced it. This concept of archaeological visibility is a sort of "algebraic sum", including the Otherness of the Past, the correspondence between systemic and archaeological contexts (sensu Schiffer, 1972), the residuality of the archaeological context, the magnitude of the palimpsest effect, the intensity of the archaeological signal and the ambiguity of the archaeological record (Spagnolo et al., 2019 and reference therein). The intrinsic ambiguity of the archaeological data, in particular, severely hinders a clear and correct reading of a context, in particular if based on a limited dataset analysis. This implies that the taphonomic evaluation of an archaeological context (representing the crucial/preliminary point of the research) must be carried out taking into account as many parameters as possible.

The approach applied is the same successfully tested for the study of several Mousterian contexts in central and southern Italy (Spagnolo, 2017).

A preliminary taphonomic step was performed in order to evaluate the preservation state of the context. The parameters adopted include the "freshness" of the findings (faunal remains, lithics and shells), the size-sorting analysis of lithics and faunal remains (Bertran et al., 2012; García-Moreno et al., 2016; Lenoble et al., 2008; Rasic, 2004; Schick, 1986, 1987; Spagnolo et al., 2016a; Stevenson, 1985, 1991) and the orientation analysis of elongated faunal remains (Benito-Calvo and de la Torre, 2011; Bertran et al., 2015; Boschian and Saccà, 2010; Cobo-Sánchez et al., 2014; Domínguez-Rodrigo et al., 2012, 2014; Domínguez-Rodrigo and García-Pérez, 2013; GarcíaMoreno et al., 2016; Giusti et al., 2018; Lenoble and Bertran, 2004; Lenoble et al., 2008; SánchezRomero et al., 2016). The size-sorting analysis and the orientation analysis have been both related to the high-resolution Digital Elevation Model (DEM) and the Slope Model (SM) of living floor 150A. A two-step size-sorting analysis was achieved, taking into account both the quantitative and spatial distribution of findings. On the one hand, the distribution of lithics by dimensional classes was compared to a theoretical model based on the experimental data-set of Bertran et al. (2012). On the other hand, the spatial behaviour of findings (both lithics and faunal remains) was evaluated in order to recognize possible size-related linear gradients or differences of spatial pattern. As far as the theoretical model used for the quantitative analysis is concerned, an asymptotic-like curve is expected to describe a typical un-disturbed knapping assemblage, with the largest proportion of 
items included in the finest size fraction (Bertran et al. 2012 and reference therein). As shown in Table 1, the dimensional classed of lithic finds used in this work are roughly comparable to the mesh-sizes of Bertran et al. (2012), making possible a quantitative comparison. Briefly, the expected values of particle size distribution should range around the $64 \%$ in the DC1 $\left(1-50 \mathrm{~mm}^{2}\right)$, the $26 \%$ in the DC2-3 $\left(50-150 \mathrm{~mm}^{2}\right)$ and the $10 \%$ in the DC4-5 $\left(>150 \mathrm{~mm}^{2}\right)$.

\begin{tabular}{|c|c|c|c|c|}
\hline \multirow{2}{*}{\multicolumn{2}{|c|}{$\begin{array}{l}\text { Lithic Dimensional Classes } \\
\text { in this work }\left(\mathrm{mm}^{2}\right)\end{array}$}} & \multicolumn{2}{|c|}{$\begin{array}{l}\text { Lithic Dimensional Classes } \\
\text { (Bertran et al. 2012) }\end{array}$} & \multirow{3}{*}{$\begin{array}{c}\text { Expected values } \\
\text { (based on mean values in } \\
\text { Bertran et al. 2012) } \\
64.3 \%\end{array}$} \\
\hline & & \multirow{2}{*}{$\begin{array}{c}\text { Sieve mesh } d(\mathrm{~mm}) \\
2-4\end{array}$} & \multirow{2}{*}{$\begin{array}{c}\text { Piece width } w(\mathbf{m m}) \\
2.8-5.7\end{array}$} & \\
\hline DC 1 & $1-50$ & & & \\
\hline DC 2 & $50-100$ & $4-5$ & $5.7-7$ & $10.7 \%$ \\
\hline DC 3 & $100-150$ & $5-10$ & $7-14$ & $15.2 \%$ \\
\hline \multirow{4}{*}{$\begin{array}{l}\text { DC } 4 \\
\text { DC } 5\end{array}$} & \multirow{4}{*}{$\begin{array}{l}150-200 \\
>200\end{array}$} & $10-20$ & $14-28$ & $5.7 \%$ \\
\hline & & $20-31.5$ & $28-44$ & $2.5 \%$ \\
\hline & & $31.5-50$ & $44-71$ & $1.2 \%$ \\
\hline & & $>50$ & $>71$ & $0.4 \%$ \\
\hline
\end{tabular}

Table 1: Comparison between Dimensional Classes adopted in this work and the ones used by Bertran et al., 2012 with related mean \% values expected by experimental collection reference.

The faunal remains sampled for the fabric analysis include all the pieces $>2 \mathrm{~cm}$ in length and with Elongation Index $\geq 1.7$ (Benito-Calvo and de la Torre, 2011; Boschian and Saccà, 2010;

Domínguez-Rodrigo et al., 2014; Domínguez-Rodrigo and García-Pérez, 2013; García-Moreno et al., 2016; Giusti et al., 2018). The two-dimensional vector drawing of faunal remains was made at scale 1:1 by means of the accurate photomap (Fig. 3) and eventually integrated with the 1:5 fieldmaps. The vector map was used to calculate the orientations of bones directly in the GIS platform (ArcGIS® 10.6.1), by means of the MBRA (Minimum Bounding Rectangle Axis). This automatic procedure, functioning in the similar way as the SLA (Symmetrical Longitudinal Axis), is an excellent indicator of the actual directionality in particular of longitudinal flat bones (DomínguezRodrigo and García-Pérez, 2013), such as fragmented diaphyses, which represent a large part of the faunal sample (4.1). The circular statistics (Rayleigh's, Watson's and Kuiper's Tests - carried out both with the von Mises and the uniform Distributions - and Rose diagrams) were performed with Oriana 4.0. More specifically, the Rayleigh's Test was aimed to identify a possible uniform-linear pattern, whilst the Watson's and Kuiper's Tests are more suitable to recognize non-uniform or bimodal/multi-modal patterns. The isotropy hypothesis cannot be rejected with $\mathrm{p}>0.05$ (BenitoCalvo and de la Torre, 2011; Cobo-Sánchez et al., 2014; Domínguez-Rodrigo et al., 2012, 2014; Domínguez-Rodrigo and García-Pérez, 2013; García-Moreno et al., 2016; Giusti et al., 2018; 
Lenoble and Bertran, 2004). The evaluation of the spatial behaviour of taphonomic parameters was based both on statistical (e.g. Ripley function) and visual (Kernel Density maps and plotting maps) methods. More specifically, the statistical approach to the point pattern analysis was performed with the L(d) transformation of the K-Ripley function, setting the confidence envelopes on 99 permutation with the Monte Carlo simulations and using the polygon of the excavated area as study area (given that the study-area changes sensitivity of this method). Moreover, the edges/boundaryeffect (produced by interrelation between point patterns and morphologies/dimension of the study area) can bias the accuracy of results. This effect is typically shown by consistent deviatedbehaviours of the expected values on the confidence envelopes. In order to avoid or limit the effect of this deviation on final results, a Boundary Correction Method was applied with the parameter “simulate outer boundary values" (e.g. Baddeley et al., 2015; Crema and Bianchi, 2013; Carrer, 2017; Conolly and Lake, 2006; Domínguez-Rodrigo et al., 2018; Giusti and Arzarello, 2016; Marín et al., 2019; Negre et al., 2019; Ripley, 1976, 1977; Romagnoli and Vaquero, 2016; Spagnolo et al., 2016, 2019, accepted; Thacher et al., 2017).

In agreement with the sample size, the behaviourally significant data for the spatial patterns include lithic micro-debris $\left(\mathrm{DC}=1-50 \mathrm{~mm}^{2}\right.$ ), lithic tools (both retouched tools and items with micro-traces compatible with use), cores, hammer-stones/pebbles, unburnt smaller faunal remains $(1-3 \mathrm{~cm})$, unburnt larger faunal remains $(>10 \mathrm{~cm})$, burnt faunal remains, faunal remains with cut-marks and/or notches, cones and marine malacofauna. The set of spatial-functional analyses performed includes: L(d) transformation of the K-Ripley function, Kernel Density (e.g. Blasco et al., 2016; Moroni et al., in press; Oron and Goren-Inbar, 2014; Spagnolo et al., 2016a, 2019, accepted; Thacher et al., 2017), visual maps of the less numerous although significant categories and Ward's Cluster Analysis (e.g. Frahm and Tryon, 2018; Pardo et al., 2016; Shennan, 1997; Spagnolo et al., 2019, accepted; Whallon, 1984).

\section{Results}

\subsection{Zooarchaeology}

The zooarchaeological and taphonomic study of the macrofaunal assemblage was carried out on 71 identified specimens and 1,019 unidentifiable fragments (Tables 2-3).

\begin{tabular}{r|ll} 
Species & NISP & \% \\
\hline Cervus elaphus & 35 & 49.4 \\
Dama dama & 4 & 5.6 \\
Capreoulus capreolus & 1 & 1.4 \\
Cervidae indt. & 5 & 7 \\
Bos primigenius & 13 & 18.3
\end{tabular}




\begin{tabular}{r|ll} 
Bos/Bison & 7 & 9.9 \\
Equus ferus & 5 & 7 \\
Stephanorhinus sp. & 1 & 1.4 \\
Total & $\mathbf{7 1}$ &
\end{tabular}

Table 2: Number of the Identified Specimens and percentages of the macromammal assemblage.

\begin{tabular}{l|rr}
\multicolumn{1}{c}{ Element } & NR & \multicolumn{2}{c}{ \% } \\
(without others)
\end{tabular}

Table 3: Number and percentages of the unidentified remains.

Cervids $(56.4 \%)$ are the most common ungulates followed by bovids $(18.3 \%)$ which are exclusively represented by the aurochs. Among cervids, the dominant species is the red deer ( $49.4 \%$ of NISP), whilst the fallow deer and the roe deer show much lower percentages (5.6\% and $1.4 \%$ respectively). The horse is represented by few remains (7\%). A jugal tooth of Stephanorhinus sp. was identified (Pandolfi et al., 2017).

The MNI is equal to 9. Out of these, 3 are red deer (a juvenile, a prime adult and an old adult) and 2 are aurochs (both old adults). The other taxa are represented by one individual per taxon. 


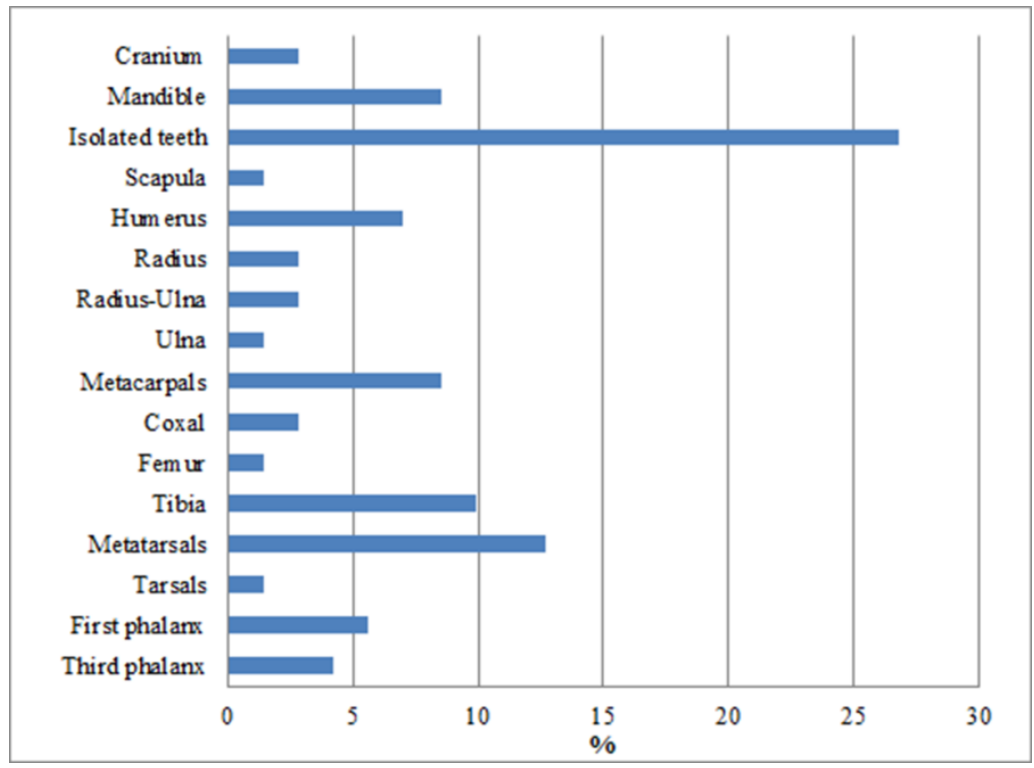

Fig. 5. Skeletal frequencies of the macromammal assemblage.

The macro-faunal association of living floor 150A suggests the existence, in the emerged plain at the foot of Monte Argentario (Moroni et al., 2019), of a composite landscape formed both by wooded environments (proved by the abundance of cervid taxa) and open areas (attested by the presence of the bovids, the rhino and the horse).

The identified sample is exclusively composed of elements of the pelvic and scapular girdles and of cranial and limb bones (Fig. 5). Specimens mostly consist of isolated teeth (26.8\%) and diaphysis fragments (42.2\%), among which tibiae and metapodials (mainly belonging to cervids) are the most represented (Table 3). Due to the unique morphology of their shafts, these bones are more identifiable than diaphysis portions of other long bones. For this reason, tibiae and metapodials have probably been overestimated. No carpal bone has been identified and phalanges and tarsal bones are scarce (1.4\% and $9.8 \%$ respectively).

Anthropogenic marks were detected on $35.2 \%$ of the identified remains (21\% percussion marks and $14.2 \%$ cut marks). Only a single gnawing mark by carnivores (on a first phalanx of Cervus elaphus) was recorded.

The observation of Freshness Fracture Index (FFI) carried out on 25 identified specimens shows values mainly comprised between 0 and 2 , thus indicating that fractures were performed when bones were still fresh. 


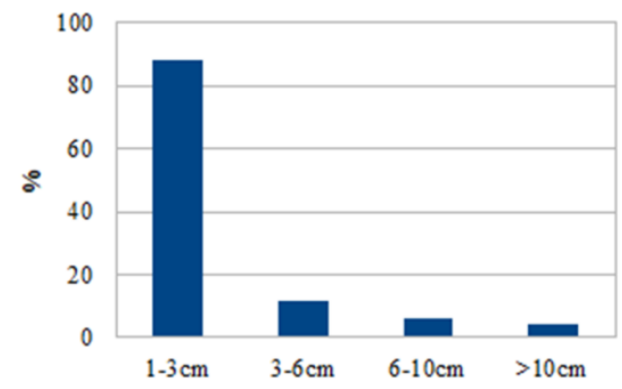

Fig. 6. Fragmentation of unidentified sample.

The unidentified remains appear to be highly fragmented: $83.7 \%$ falls in the class $1-3 \mathrm{~cm}$ (Fig. 6). In this sample diaphysis fragments are the most abundant (46.4\%), followed by ribs (12\%), spongy bones (10.6\%), and skull fragments (7.4\%) (Table 3). Anthropogenic marks are present on $2.2 \%$ of the unidentified specimens, while gnawing traces by carnivores are completely absent. Burnt bones are very scant ( $3.1 \%$ of the unidentified sample).

\subsection{Lithics}

\subsubsection{Technology}

The lithic sample of living floor $150 \mathrm{~A}$ consists of 116 items in a good state of preservation, with fresh edges and well-preserved macro and micro traces.

The raw material consists mainly of red and dark radiolarite (41.4\%), found both in the form of pebbles and blocks with traces of rolling as well as smooth, fine grey, and dark green small chert pebbles (28.4\%). A component consisting of siliceous limestone (22.4\%) and few limestone and $(1.7 \%)$ quartz $(0.9 \%)$ artifacts are also present (Table 4$)$. Specific studies on the supply of raw materials have not yet been tackled, but they are in agenda and partially ongoing (Scaramucci, 2018). The metamorphic component (e.g. quartz) of the industry can be probably linked to the Verrucano formation of the Monte Argentario promontory (Segre, 1959). The rounded siliceous pebbles, instead, are from fluvial (e.g. the Albegna river) and nearby beach deposits. This is a factor which argues in favour of a local supply of most of the raw material, possibly coming both from the formations cropping out close to the cave, and from now submerged alluvial deposits (Moroni et al., 2019).

\begin{tabular}{|c|c|c|c|c|c|c|c|c|c|c|c|c|}
\hline \multirow{3}{*}{ Raw Material } & \multirow{2}{*}{\multicolumn{2}{|c|}{$\frac{\text { DC } 1}{\left(1-50 \mathrm{~mm}^{2}\right)}$}} & \multirow{2}{*}{\multicolumn{2}{|c|}{$\frac{\text { DC } 2}{\left(50-100 \mathrm{~mm}^{2}\right)}$}} & \multirow{2}{*}{\multicolumn{2}{|c|}{$\frac{\text { DC } 3}{\left(100-150 \mathrm{~mm}^{2}\right)}$}} & \multirow{2}{*}{\multicolumn{2}{|c|}{$\frac{\text { DC } 4}{\left(150-200 \mathrm{~mm}^{2}\right)}$}} & \multirow{2}{*}{\multicolumn{2}{|c|}{$\frac{\text { DC 5 }}{\left(>200 \mathrm{~mm}^{2}\right)}$}} & \multirow{2}{*}{\multicolumn{2}{|c|}{ Total }} \\
\hline & & & & & & & & & & & & \\
\hline & n. & $\%$ & n. & $\%$ & n. & $\%$ & n. & $\%$ & n. & $\%$ & n. & $\%$ \\
\hline Radiolarite & 10 & 62.5 & 7 & 35.0 & 6 & 50.0 & 3 & 37.5 & 22 & 44.0 & 48 & 41.4 \\
\hline
\end{tabular}




\begin{tabular}{|l|c|c|c|c|c|c|c|c|c|c|c|c|} 
Chert & 5 & 31.3 & 4 & 20.0 & 3 & 25.0 & 3 & 37.5 & 18 & 36.0 & 33 & 28.4 \\
\hline Siliceous limestone & 8 & 50.0 & 8 & 40.0 & 3 & 25.0 & 1 & 12.5 & 6 & 12.0 & 26 & 22.4 \\
\hline Limestone & 2 & 12.5 & 0 & 0.0 & 0 & 0.0 & 0 & 0.0 & 0 & 0.0 & 2 & 1.7 \\
\hline Quartz & 0 & 0.0 & 0 & 0.0 & 0 & 0.0 & 0 & 0.0 & 1 & 2.0 & 1 & 0.9 \\
\hline Indeterminable & 1 & 6.3 & 1 & 5.0 & 0 & 0.0 & 1 & 12.5 & 3 & 6.0 & 6 & 5.2 \\
\hline Total & 16 & \multicolumn{2}{|c|}{20} & & 12 & & 8 & & 50 & & 116 & \\
\hline$\%$ & $\mathbf{1 3 . 8}$ & \multicolumn{3}{|c|}{$\mathbf{1 7 . 2}$} & \multicolumn{3}{|c|}{$\mathbf{1 0 . 3}$} & \multicolumn{6}{|c|}{$\mathbf{6 . 9}$} & $\mathbf{4 3 . 1}$ & & \\
\hline
\end{tabular}

Table 4: Raw material and Dimensional classes of lithic implements.

\begin{tabular}{r|cc} 
Technological classes & $\boldsymbol{n .}$ & $\boldsymbol{\%}$ \\
\hline Pebbles & 2 & 1.7 \\
Hammer-stones & 4 & 3.4 \\
Flakes & 48 & 41.4 \\
Micro-Flakes & 24 & 20.7 \\
Cores & 5 & 4.3 \\
Debris & 22 & 19.0 \\
Undetermined & 11 & 9.5 \\
$\%$ & $\mathbf{1 1 6}$ &
\end{tabular}

Table. 5: Technological classes.

Half of the lithics (43.1\%) (Table 4), are included in the larger dimensional class (DC 5: > 200 $\mathrm{mm}^{2}$ ). The technological study is focused on the most discriminant items, namely 5 cores and 48 flakes which document different reduction sequences (Table 5). That is to say: we note the presence of several fragments from various reduction sequences, mainly pertaining to the Levallois concept (22 items) and volumetric unipolar debitage (5 items) (Table 6). Given the paucity of the sample it was not always possible to ascertain the debitage concept as flakes obtained by different reduction sequences may show similar or even identical technical characteristics (Table 6). Nevertheless, we note a phase of pebble opening attested by the presence of completely cortical and semi-cortical flakes. Half of the flakes show a cortical coverage; in particular there are some which have their cortex in the lateral position. Many flakes have cortical parts on the dorsal face as the starting pebbles are quite small: after the first phase of cortex removal and the first extraction of flakes the core was already destructured and depleted. There are rarely more than three negatives on the dorsal face of flakes. The directions of the removals are mostly unipolar and convergent (unipolar 23, convergent 9, orthogonal 5, centripetal 2). The butts are mostly faceted (11), flat (8) and dihedral (6), with a central point of impact (20) and bulbs are prominent or slightly prominent, attesting a direct percussion technique.

\begin{tabular}{|c|c|c|c|c|c|}
\hline $\begin{array}{c}\text { Technological Category } \\
\text { Concept of debitage }\end{array}$ & Levallois & $\begin{array}{c}\text { Volumetric } \\
\text { unidirectional }\end{array}$ & Indeterminated & \multicolumn{2}{|c|}{ Total } \\
\cline { 2 - 6 } & N. & N. & N. & N. & $\%$ \\
\hline
\end{tabular}




\begin{tabular}{|l|r|r|r|r|r|} 
Core & 2 & 3 & $\mathbf{5}$ & $\mathbf{9 . 4}$ \\
\hline Completely-Cortical Flakes & & & 2 & $\mathbf{2}$ & $\mathbf{3 . 8}$ \\
\hline Semi-cortical flakes & & & 6 & $\mathbf{6}$ & $\mathbf{1 1 . 3}$ \\
\hline Management flakes & 7 & 2 & 17 & $\mathbf{2 6}$ & $\mathbf{4 9 . 1}$ \\
\hline Pseudo-Levallois points & & & 1 & $\mathbf{1}$ & $\mathbf{1 . 9}$ \\
\hline Target long backed flakes & 6 & & $\mathbf{6}$ & $\mathbf{1 1 . 3}$ \\
\hline Target convergent flakes & 2 & & & $\mathbf{2}$ & $\mathbf{3 . 8}$ \\
\hline Target long flakes & 5 & & & $\mathbf{5}$ & $\mathbf{9 . 4}$ \\
\hline Total & $\mathbf{2 2}$ & $\mathbf{5}$ & $\mathbf{2 6}$ & $\mathbf{5 3}$ & \\
\hline \% & $\mathbf{4 1 . 5}$ & $\mathbf{9 . 4}$ & $\mathbf{4 9 . 1}$ & & \\
\hline
\end{tabular}

Table 6: Technological categories and concept of debitage (considering flakes and cores).

\begin{tabular}{|c|c|c|c|c|c|c|c|c|}
\hline \multirow{2}{*}{$\begin{array}{c}\text { Technological Category } \\
\text { Amount of cortex }\end{array}$} & \multirow{2}{*}{0} & \multirow{2}{*}{0 to $25 \%$} & \multirow{2}{*}{25 to $50 \%$} & \multirow{2}{*}{50 to $75 \%$} & \multirow{2}{*}{75 to $100 \%$} & \multirow{2}{*}{$100 \%$} & \multicolumn{2}{|c|}{ Total } \\
\hline & & & & & & & $n$ & $\%$ \\
\hline Completely-Cortical Flakes & & & & & & 2 & 2 & 4.2 \\
\hline Semi-cortical flakes & & & & & 6 & & 6 & 12.5 \\
\hline Management flakes & 13 & 6 & 2 & 5 & & & 26 & 54.2 \\
\hline Pseudo-Levallois points & 1 & & & & & & 1 & 2.1 \\
\hline Target long backed flakes & 2 & 4 & & & & & 6 & 12.5 \\
\hline Target convergent flakes & 2 & & & & & & 2 & 4.2 \\
\hline Target long flakes & 1 & 1 & 3 & & & & 5 & 10.4 \\
\hline Total & 19 & 11 & 5 & 5 & 6 & 2 & 48 & \\
\hline$\%$ & 39.6 & 22.9 & 10.4 & 10.4 & 12.5 & 4.2 & & \\
\hline
\end{tabular}

Table 7: Technological categories and cortex amount of flakes. 

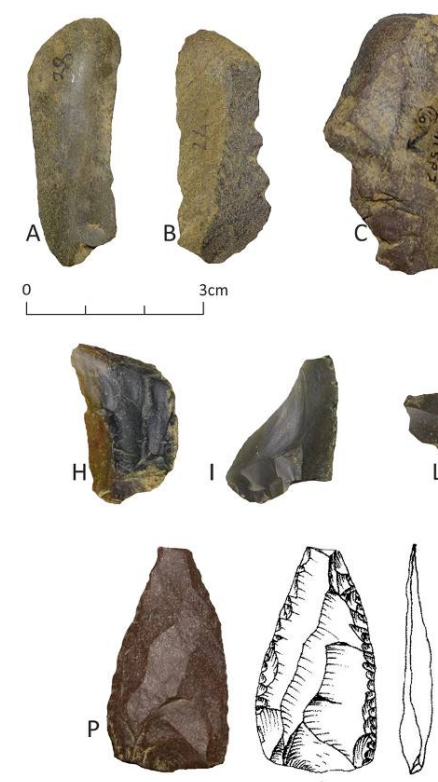

in
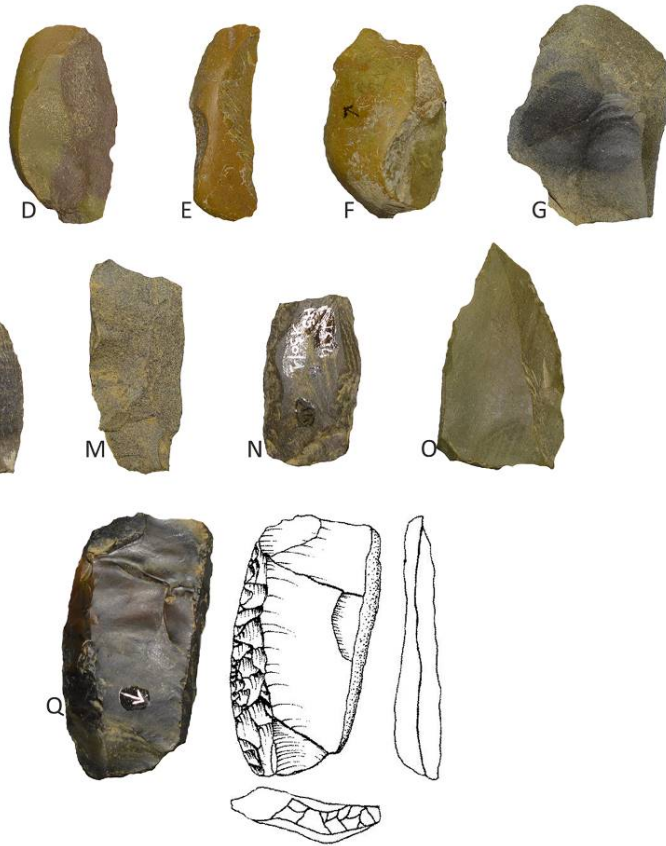

Fig. 7. Technological categories of flakes: A: Completely-Cortical Flakes; B, C, E, F: Semi-cortical flakes; G, H, I: Management flakes; L: Pseudo-Levallois point, D, Q: Target long backed flakes; O, P: Target convergent flakes; M, N: Target long flakes. P: Retouched point, Q: side scraper (P, Q: Drawings modified from Moroni et al., 2018).

Some blanks were selected to be retouched, namely: 5 target items, 3 management flakes and 1 semi-cortical flake). We note that retouched flakes are larger (between 4.5 and $3.3 \mathrm{~cm}$ ) than the majority of the other items of the collection (smaller than $3 \mathrm{~cm}$ ) (i.e. Fig. 7q). Moreover, one of them, a retouched point, was produced by a fully Levallois production with several negatives on the dorsal face indicating a phase of plain debitage, and an elaborate preparation that implies the exploitation of larger cores (i.e. Fig. 7p). This evidence led us to hypothesise the arrival at the site of such tools as already finished objects.

There are only five cores and we identified two reduction concepts: Levallois and unidirectional volumetric debitage. The unidirectional additional debitage is characterized by an opening of the striking platform with an orthogonal strike followed by a series of mostly unipolar scars. It is the case of core C (Fig. 8) both the thinner and larger side of the pebble was used as debitage surface. These cores show different hinged accidents that could have caused the core abandonment. 
The Levallois recurrent unipolar and convergent cores show striking platforms prepared with small detachments followed by few removals aiming at removing the cortex and producing the objectives of debitage. Constraints due to the small size of the starting blocks do not allow the structuring of the lateral and distal convexity typical of Levallois (Fig. 8a-b), but actually in this case, the selection of pebbles with a lenticular shape and natural convexities suitable to this method seems to replace the initialization phase (Marciani, 2018). Beside the paucity of the core sample, only for 5 items, we note a selection of a different initial shape of the block according to each debitage concept: for the unidirectional additional cores angular volumes were selected, while for the Levallois lenticular flattened pebbles were preferred.
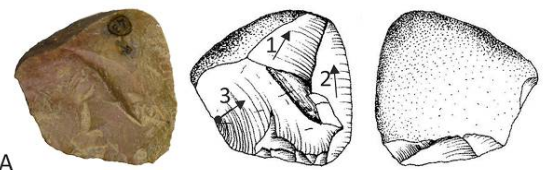

B
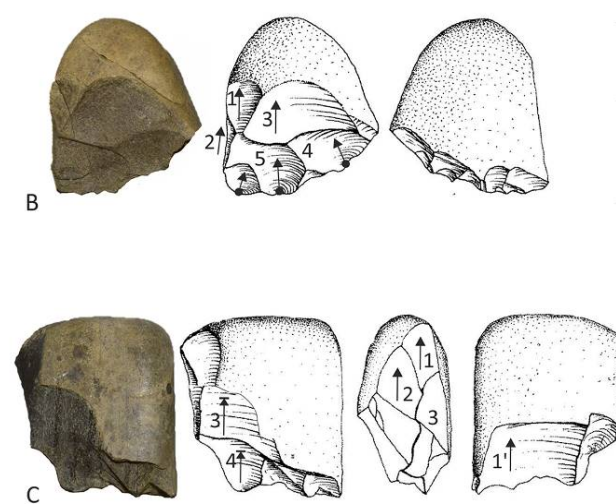

$3^{3 \mathrm{~cm}}$ Direction

.Direction and cotra-bulb

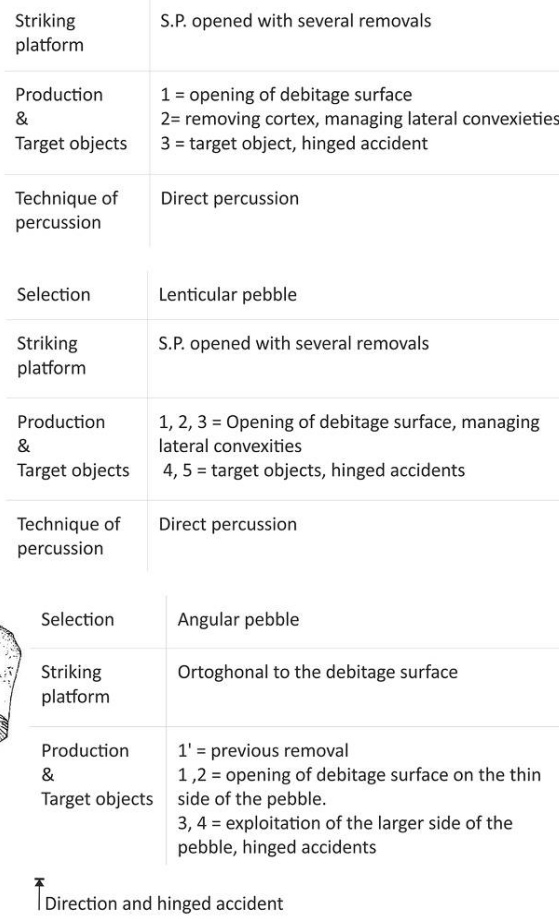

Striking platform Production \& Target objects

Technique of percussion

$\Upsilon_{\text {Direction and hinged accident }}$

Ortoghonal to the debitage surface

Oroghonal to the debitase

\begin{abstract}
-
\end{abstract}
Fig. 8. Diacritical analysis of cores. A, B: Levallois core; C: unidirectional core (Drawings modified from Moroni et al., 2018).

Furthermore, we note two types of hammerstones, one of a larger size and three of a smaller size. These three have an ellipsoidal shape and very similar dimensions (respectively length, width and 
thickness expressed in mm: 49-31-9; 45-25-8; 48-34-8). These common technical characteristics allow us to hypothesise the selection of these elements for a possible retouching action, performed both with the wide and with the narrow surface of the pebble.

\subsubsection{Traceology}

The lithic sample usually boasts very well-preserved edges and surfaces, only few items (4) are affected by mechanical and chemical alterations related to post-depositional processes. Diagnostic traces were detected on 4 artefacts (a pseudo-levallois point and 3 target long flakes). The pseudolevallois point displays well developed use-wear associable to butchering activity (Fig. 9). This item was used in mixed motion of cutting combined with scraping, involving fleshy and hard tissue. The active portion of this artefact is formed by the two lateral edges (one is convex and the other rectilinear). Use-wear involves only half of the edges in their distal part.

\begin{tabular}{l|ccccc} 
& Use-wear & $\begin{array}{c}\text { Post-dep. } \\
\text { alterations }\end{array}$ & Unused & Uncertain & Total analysed \\
\hline Target convergent flake & 1 & & 1 & & 1 \\
Pseudo-levallois point & 3 & 2 & 3 & 1 & 1 \\
Target long flakes & 4 & 2 & 4 & 1 & 11 \\
Total analysed & & & &
\end{tabular}

Table 8: Total amount of pieces examined for use-wear analysis

The target long flakes exhibit less developed traces, consisting in edge rounding, micro-scarring and weakly polishing. All these items could be used for cutting soft material, probably fleshy tissue (Table 8). The active portions of these flakes are in lateral position and occupy $3 / 4$ of the tool totality. They have rectilinear (2) or convex (1) delineations. 

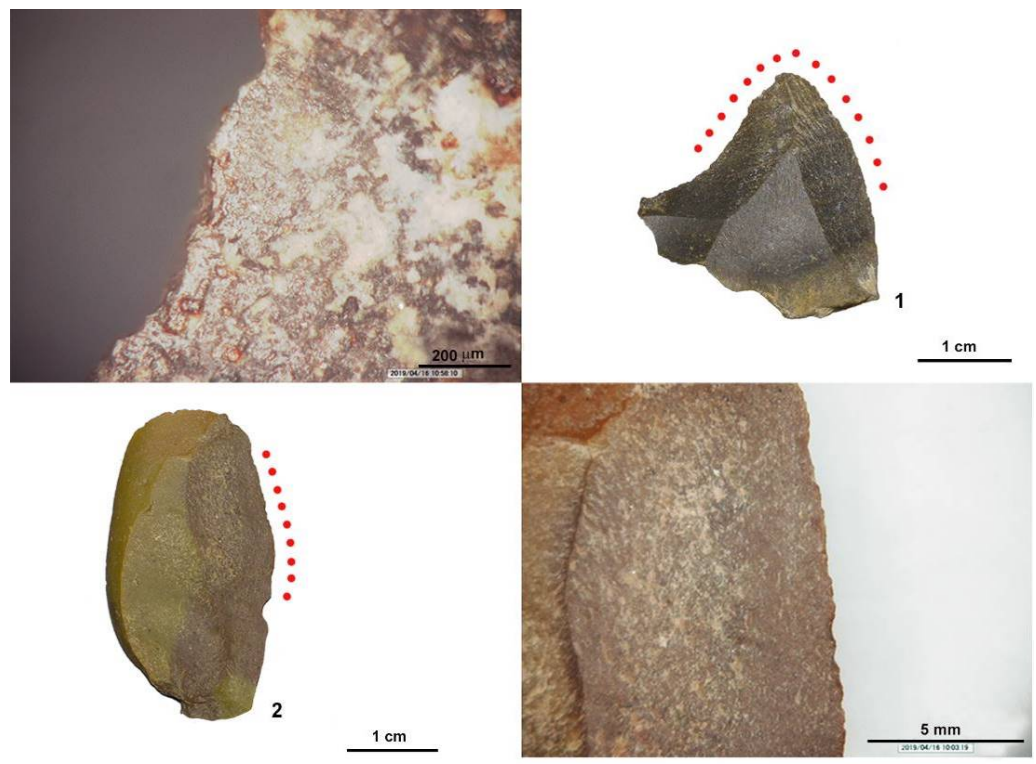

Fig. 9. Pseudo-levallois flake (1) showing macro and micro use-wears (dotted line) due to processing fleshy and hard tissues through mixed actions; in detail, rough polish. Target long flake (2) showing macro use-wear (dotted line); in detail edge damage interpreted as the result of cutting soft material.

\subsection{Malacological sample}

\subsubsection{Taxonomy}

The malacological assemblage includes 279 remains (19 unidentifiable and 260 identified), belonging to 7 taxa (Table 9). Among the gastropods only 3 fragments of Patella sp. and a whole specimen of Naticarius hebraeus have been identified. The most representative bivalve species are Callista chione $(\mathrm{NISP}=190 ;$ MNVtot $=19)$ and Mytilus galloprovincialis $(\mathrm{NISP}=60 ; \mathrm{NMVtot}=$ 6). Acanthocardia sp. and Pecten jacobaeus are represented by 4 fragments without significant landmarks for the MNV.

The infralittoral zone with sandy/muddy seabed constitutes the typical habitat for the majority of the species found in 150A. However, the occurrence of limpets and mussels testifies to the additional presence of cliff environments.

\begin{tabular}{|l|l|l|l|l|l|l|l|}
\hline & $\mathrm{Nr}$ & NISP & MNI & MNVright & MNVleft & Habitat & Substrate \\
\hline Gastropoda & & & & & & & \\
\hline Patella sp. & 3 & 3 & - & - & - & Supra/Mediolittoral & Hard \\
\hline
\end{tabular}




\begin{tabular}{|l|l|l|l|l|l|l|l|}
\hline Naticarius hebraeus & 1 & 1 & 1 & - & - & Infralittoral & Soft \\
\hline Unident. Gastropoda & 2 & 2 & - & - & - & - & - \\
\hline Bivalvia & & & & & & & \\
\hline Mytilus galloprovincialis & 60 & 60 & - & 5 & 1 & Medio/Infralittoral & Hard \\
\hline Pecten jacobaeus & 1 & 1 & - & - & - & Infralittoral & Soft \\
\hline Acanthocardia sp. & 3 & 3 & - & - & - & Infralittoral & Soft \\
\hline Callista chione & 190 & 190 & - & 11 & 8 & Infralittoral & Soft \\
\hline Unidentified taxa & 19 & - & - & - & - & - & - \\
\hline Total & $\mathbf{2 7 9}$ & $\mathbf{2 6 0}$ & $\mathbf{1}$ & $\mathbf{1 6}$ & $\mathbf{9}$ & & \\
\hline
\end{tabular}

Table 9: Mollusc species found in living floor 150A.

\subsubsection{Taphonomy}

The main taphonomic processes that affected the malacological set include decalcification $(25.3 \%)$ and post-depositional fragmentation (26.8\%). The presence of white surfaces with exfoliations (recorded on $77.7 \%$ of the specimens) can be connected to the loss of minerals from the tissue. This process entails an increment of shell fragility and can explain the high frequency of postdepositional fractures. Excluding the fragments with carbonate coating, 39.2\% of the specimens display bio-erosional traces (both on the ventral and dorsal side of the shell). A single item shows evidence of predation. Dot-like thermal alterations are recorded on $7.7 \%$ of the sample (including M. galloprovincialis and C. chione specimens only) (Fig. 10). Traces of charcoal are present on $8.5 \%$ of the specimens and are recorded both on the dorsal and ventral side of the shell and on the fractured edges (Table 10).

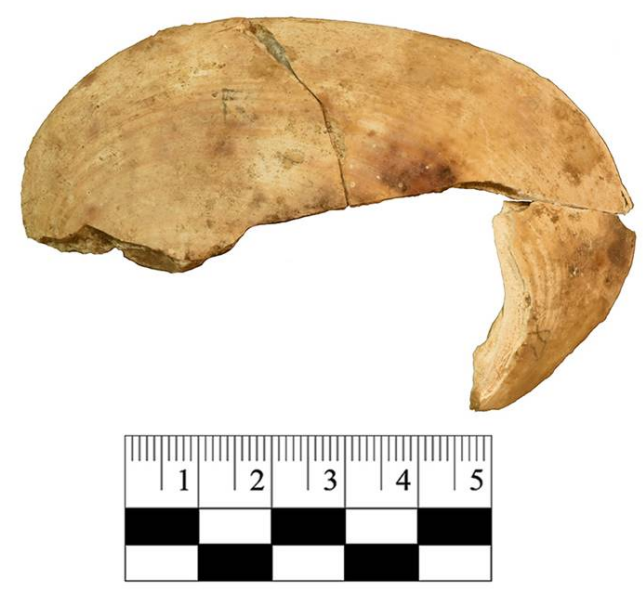

Fig. 10. Photo of a refitted specimen of Callista chione with dot-like thermal alterations. 
affects only the proximal one. This evidence suggests that the exposition of the valve proximal fragment to thermal agents took place after the shell breakage.

\begin{tabular}{|c|c|c|c|c|c|c|c|c|c|c|c|c|c|c|}
\hline & \multirow[b]{2}{*}{$\frac{\hat{\sigma}}{\bar{Z}}$} & \multirow[b]{2}{*}{$\frac{\grave{a}}{\bar{z}}$} & \multicolumn{3}{|c|}{ BioEr } & \multirow{2}{*}{$\frac{\mathrm{d}}{\mathrm{e}}$} & \multirow[b]{2}{*}{ 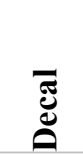 } & \multirow{2}{*}{$\frac{0}{2}$} & \multirow[b]{2}{*}{ 氙 } & \multirow[b]{2}{*}{$\begin{array}{l}\stackrel{0}{0} \\
\stackrel{0}{0}\end{array}$} & \multirow[b]{2}{*}{ ర్ల } & \multirow{2}{*}{ రુ } & \multirow[b]{2}{*}{$\stackrel{\Xi}{\rightleftarrows}$} & \multirow{2}{*}{ 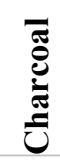 } \\
\hline & & & Int & Ext & Both & & & & & & & & & \\
\hline Patella sp. & 3 & - & - & - & 2 & - & - & 2 & - & - & - & - & - & - \\
\hline Naticarius hebraeus & 1 & - & - & - & - & - & 1 & 1 & 1 & - & 1 & - & - & - \\
\hline Unident. Gastropoda & 2 & - & - & - & - & - & 2 & - & - & - & - & - & - & - \\
\hline Mytilus galloprovincialis & 60 & - & 4 & - & - & - & 21 & 52 & 12 & - & 21 & 24 & 7 & 5 \\
\hline Pecten jacobeus & 1 & - & - & - & 1 & - & 1 & 1 & - & - & - & - & - & - \\
\hline Acanthocardia sp. & 3 & - & - & 2 & 1 & - & 3 & 3 & 1 & - & 2 & 2 & - & - \\
\hline Callista chione & 190 & 1 & 24 & 19 & 49 & 1 & 174 & 155 & 35 & 3 & 50 & 86 & 13 & 17 \\
\hline Total & 260 & 1 & 28 & 21 & 53 & 1 & 202 & 214 & 49 & 3 & 74 & 112 & 20 & 22 \\
\hline Total taph. (\%) & & 0.1 & 3.5 & 2.6 & 6.6 & 0.1 & 25.3 & 26.8 & 6.1 & 0.4 & 9.3 & 14.0 & 2.5 & 2.8 \\
\hline Total NISP (\%) & & 0.4 & 10.8 & 8.1 & 20.4 & 0.4 & 77.7 & 82.3 & 18.8 & 1.2 & 28.5 & 43.1 & 7.7 & 8.5 \\
\hline
\end{tabular}

Table 10: List of taphonomic processes by identified marine taxa. Abbreviations: Nabr - natural abrasion; BioEr - bio-erosion; Int - ventral side; Ext - dorsal side; Both - Both side; Apred animal predation; Decal - decalcification; PdepD - post-depositional damage; EscD - escavation damage; Roots - roots damage; $\mathrm{CaCO} 3$ - calcium carbonate crust; TAlt - Termo-alteration damage; Charcoal - charcoal crust; Total taph. - total taphonomic processes; Total NISP - total Number of Identified Specimens. Note: some specimens could have been exposed to more than one type of taphonomic alterations.

\subsection{Spatial evidence}

\subsubsection{Spatial taphonomy}

Different preservation degrees characterize the different areas of living floor 150A. A significant part of the original deposit was destroyed by the Holocene marine erosion, including its E-NE edge. Possible bioturbations have been identified in squares I4-I5 (where two $10 \mathrm{~cm}$ wide channels are present) and partly in squares G6-G7 (where a wider channel is documented). Therefore these sectors have been excluded from our study (Fig. 3).

The horizontality of the living-floor shown by DEM and SM (Fig. S1) constitutes a likely conservative factor for the spatial patterns in relation to gravitational and/or tractive disturbances. Nevertheless, the low extent of the excavated area limits a wide-range reading of the evidence. The presence of thermally altered sediments in square H5 is what remains of a fireplace, whose ash and/or charcoals are not preserved.

The quantitative-based distribution pattern of the lithic sample is characterized by a higher proportion of larger items, with a clear underrepresentation of the smallest dimensional class, if 
compared with the theoretical values of Table 1 (Table 4). Regarding the spatial-based size-sorting analysis the L(d) Ripley's function highlights size-dependent variations in the spatial patterns (in terms of increment/decrement of the clustering rate) of the faunal remains and lithic finds. In the set of faunal remains, some clear clustered patterns are recognizable among the smaller fragments (1-3 and 3-6 cm) and a moderate clustering rate is visible among the larger fragments $(>10 \mathrm{~cm})$, highlighting a general trend to clustering decrease increasing the Dimensional Class. Conversely, in the lithic set a trend towards an increase in clustering can be detected from the smaller to the larger dimensional classes. The highest clustering rates tend to range around $0.5 \mathrm{~m}$ radius (Fig. S2). The evidence from the density and visual maps of the dimensional classes seems not consistent with linear size-sorted assemblages (Fig. 11a-e). 

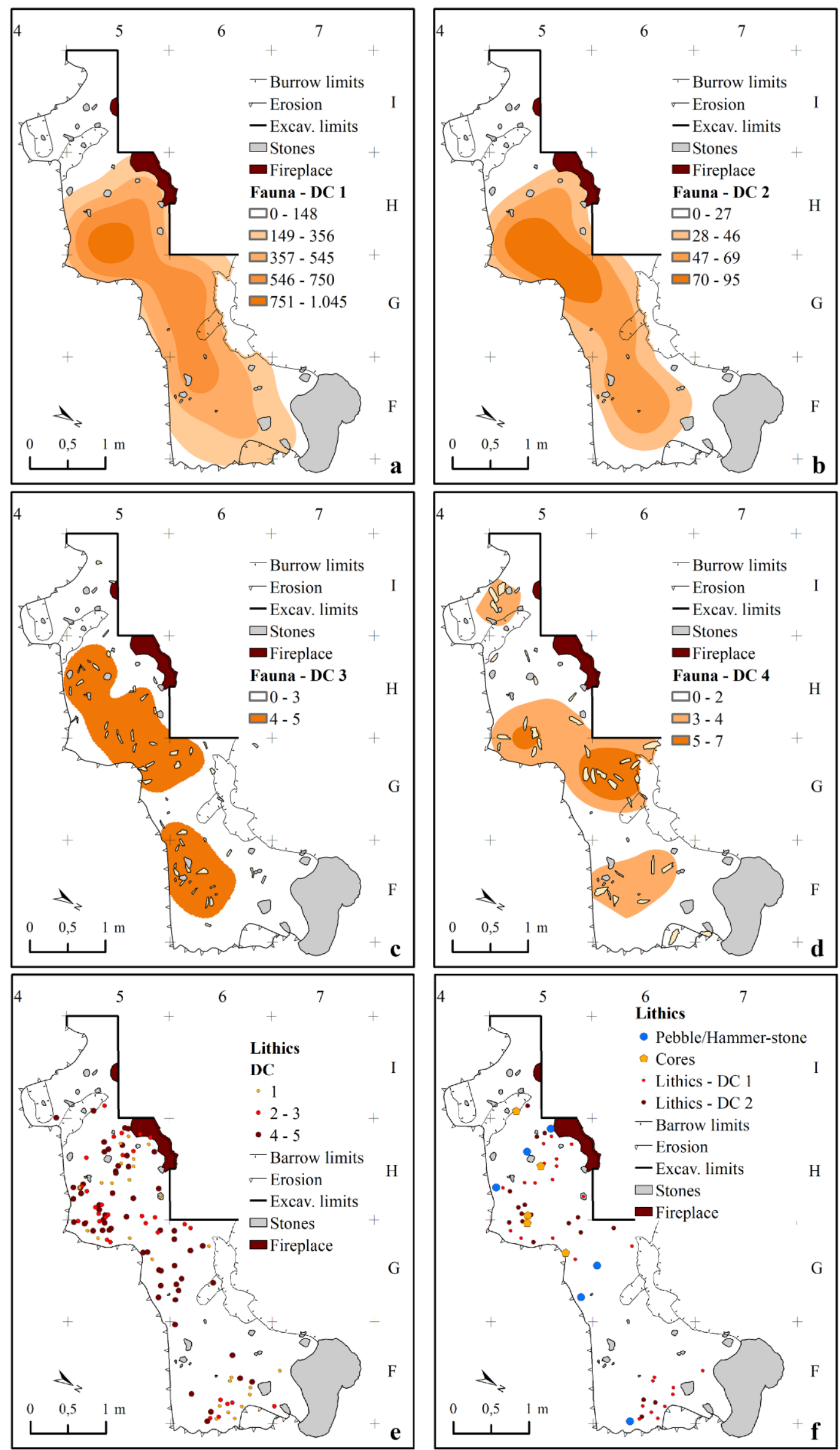
Fig. 11. Density maps and visual maps of faunal remains sorted by dimensional classes (a: DC1; b: DC 2; c: DC 3; d: DC 4), lithics sorted by dimensional classes (e) and lithic finds sorted by microdebris, cores and pebbles/hammer-stones (f).
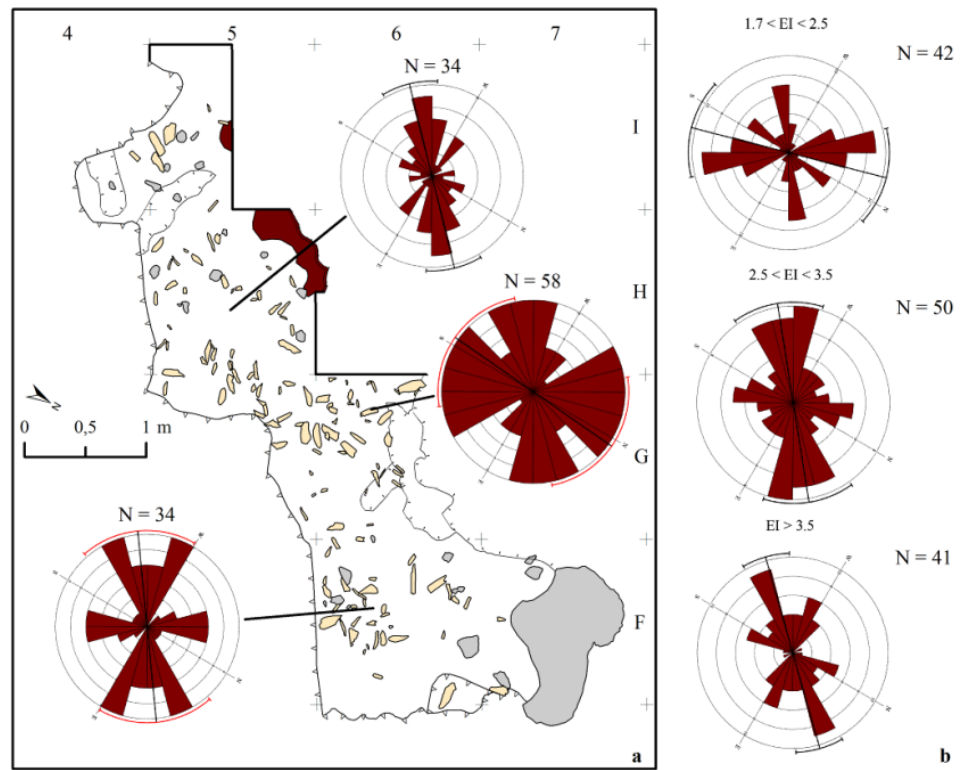

Fig. 12. Visual representation of the orientation analysis results, by squares (a) and by Elongation Index (b).

A two-way orientation analysis was performed, setting the sample on the basis of two criteria: the first one groups the faunal remains in relation to their Elongation Index (case $\mathrm{A}=1.7 \leq \mathrm{EI}<2.5$; case $\mathrm{B}=2.5<\mathrm{EI}<3.5$; case $\mathrm{C}=\mathrm{EI}>3.5$ ), the second one to their spatial localization (case $\mathrm{E}=$ Squares F7-F6; case F = Squares G6-G5; case G = Square H5-I5). The rose diagrams related to the EI criterion suggest different pattens among the case $\mathrm{A}$ and the cases $\mathrm{B}$ and $\mathrm{C}$ respectively. A bimodal cross-patterned orientation seems to characterize the bones with Elongation Index $\leq 2.5$, with a main NW-SE orientation and a secondary one perpendicular (Fig. 12b). The cases B and C seem to be characterized by a SW-NE and a SSW-NNE uniform-linear patterns respectively (Fig. 12b). As far as the spatial criterion is concerned, a strongly linear iso-oriented pattern is evident only in square $\mathrm{H} 5$, while other zones return more isotropic-like patterns (with weak suggestions of cross-patterned orientations) (Fig. 12a). The statistical analysis partially confirms this visual observation. Statistically significant anisotropic patterns are highlighted by the Rayleigh's, Watson's (with the uniform distribution) and Kuiper's (with the uniform distribution) tests both in 
square H5 (case G) and among the most elongated faunal remains (case C). Moreover, the bimodal cross-patterned orientation detected by rose diagrams among the faunal remains with EI $<2.5$ (case A) seems to be highlighted by the Watson $\mathrm{U}^{2}$ Test (carried out with the von Mises distribution). The isotropy hypothesis cannot be rejected among the bones with $2.5<\mathrm{EI}<3.5$ (case B), in F7-F6 (case E) and G6-G5 (case F) (Fig. 12; Tables 11-12).

\section{$1.7<$ EI $<2.5 \quad 2.5<$ EI $<3.5 \quad$ EI $>3.5$}

\begin{tabular}{|c|c|c|c|}
\hline Data Type & Axial & Axial & Axial \\
\hline Number of Observations & 42 & 50 & 41 \\
\hline Mean Vector $(\mu)$ & $164.065^{\circ}$ & $50.574^{\circ}$ & $43.773^{\circ}$ \\
\hline Length of Mean Vector (r) & 0.214 & 0.21 & 0.423 \\
\hline Median & $162.5^{\circ}$ & $47^{\circ}$ & $39^{\circ}$ \\
\hline Concentration & 0.437 & 0.43 & 0.934 \\
\hline Circular Variance & 0.393 & 0.395 & 0.288 \\
\hline Circular Standard Deviation & $50.343^{\circ}$ & $50.594^{\circ}$ & $37.559^{\circ}$ \\
\hline Standard Error of Mean & $14.469^{\circ}$ & $13.473^{\circ}$ & $7.114^{\circ}$ \\
\hline \multirow[t]{2}{*}{$95 \%$ Confidence Interval $(-/+)$ for $\mu$} & $135.699^{\circ}$ & $24.162^{\circ}$ & $29.826^{\circ}$ \\
\hline & $192.43^{\circ}$ & $76.986^{\circ}$ & $57.72^{\circ}$ \\
\hline \multirow{2}{*}{$99 \%$ Confidence Interval $(-/+)$ for $\mu$} & $126.789^{\circ}$ & $15.866^{\circ}$ & $25.445^{\circ}$ \\
\hline & $201.341^{\circ}$ & $85.282^{\circ}$ & $62.101^{\circ}$ \\
\hline \multicolumn{4}{|l|}{ One Sample Tests } \\
\hline Rayleigh's Test (Z) & 1.915 & 2.21 & 7.35 \\
\hline Rayleigh's Test (p) & 0.148 & 0.11 & 0.000492 \\
\hline Watson's U² Test (Uniform, $\mathrm{U}^{2}$ ) & 0.174 & 0.158 & 0.406 \\
\hline Watson's U² Test (p) & $0.1>p>0.05$ & $0.1>p>0.05$ & $<0.005$ \\
\hline Kuiper's Test (Uniform, V) & 1.647 & 1.742 & 2.412 \\
\hline Kuiper’s Test (p) & $0.10>p>0.05$ & $0.10>p>0.05$ & $<0.01$ \\
\hline Watson's U² Test (von Mises, $\mathrm{U}^{2}$ ) & 0.078 & 0.043 & 0.046 \\
\hline Watson's U² Test (p) & $<0.025$ & $0.25>p>0.15$ & $0.5>p>0.25$ \\
\hline Kuiper's Test (von Mises, V) & 1.149 & 1.121 & 1.012 \\
\hline Kuiper's Test (p) & $>0.15$ & $>0.15$ & $>0.15$ \\
\hline
\end{tabular}

Table 11: Results of the statistical analysis of the orientation of elongated bones by EI.

\begin{tabular}{l|lll|}
\multicolumn{1}{c}{} & F7-F6 & G6-G5 & H5 \\
\hline Data Type & Axial & Axial & Axial \\
Number of Observations & 34 & 58 & 34 \\
Mean Vector $(\mu)$ & $54.053^{\circ}$ & $4.549^{\circ}$ & $45.912^{\circ}$ \\
Length of Mean Vector $(r)$ & 0.191 & 0.119 & 0.381 \\
Median & $42^{\circ}$ & $4^{\circ}$ & $47^{\circ}$ \\
Concentration & 0.39 & 0.239 & 0.825 \\
Circular Variance & 0.404 & 0.441 & 0.309 \\
Circular Standard Deviation & $52.102^{\circ}$ & $59.154^{\circ}$ & $39.783^{\circ}$ \\
Standard Error of Mean & $17.99^{\circ}$ & $22.345^{\circ}$ & $8.762^{\circ}$ \\
95\% Confidence Interval (-/+) for $\mu$ & $18.786^{\circ}$ & $320.744^{\circ}$ & $28.736^{\circ}$ \\
& $89.321^{\circ}$ & $48.354^{\circ}$ & $63.088^{\circ}$ \\
99\% Confidence Interval (-/+) for $\mu$ & $7.707^{\circ}$ & $306.984^{\circ}$ & $23.34^{\circ}$ \\
& $100.399^{\circ}$ & $62.114^{\circ}$ & $68.483^{\circ}$ \\
One Sample Tests & & & 4.943 \\
Rayleigh's Test (Z) & 1.244 & 0.816 &
\end{tabular}




\begin{tabular}{l|lll|}
\hline Rayleigh's Test (p) & 0.29 & 0.442 & $\mathbf{0 . 0 0 6}$ \\
Watson's U2 Test (Uniform, $\mathrm{U}^{2}$ ) & 0.11 & 0.082 & 0.273 \\
Watson's U2 Test (p) & $0.25>\mathrm{p}>0.15$ & $0.5>\mathrm{p}>0.25$ & $<\mathbf{0 . 0 1}$ \\
Kuiper's Test (Uniform, V) & 1.67 & 1.308 & 1.747 \\
Kuiper's Test (p) & $0.10>\mathrm{p}>0.05$ & $>0.15$ & $<\mathbf{0 . 0 5}$ \\
Watson's U2 Test (von Mises, U ${ }^{2}$ ) & 0.042 & 0.044 & 0.023 \\
Watson's U2 Test (p) & $0.5>\mathrm{p}>0.25$ & $0.25>\mathrm{p}>0.15$ & $>0.5$ \\
Kuiper's Test (von Mises, V) & 1.087 & 0.942 & 0.77 \\
Kuiper's Test (p) & $>0.15$ & $>0.15$ & $>0.15$ \\
\cline { 2 - 4 }
\end{tabular}

Table 12: Results of the statistical analysis of the orientation of elongated bones by high-density zones. Strike through values may be unreliable because of low concentration (i.e. uniform distribution). 

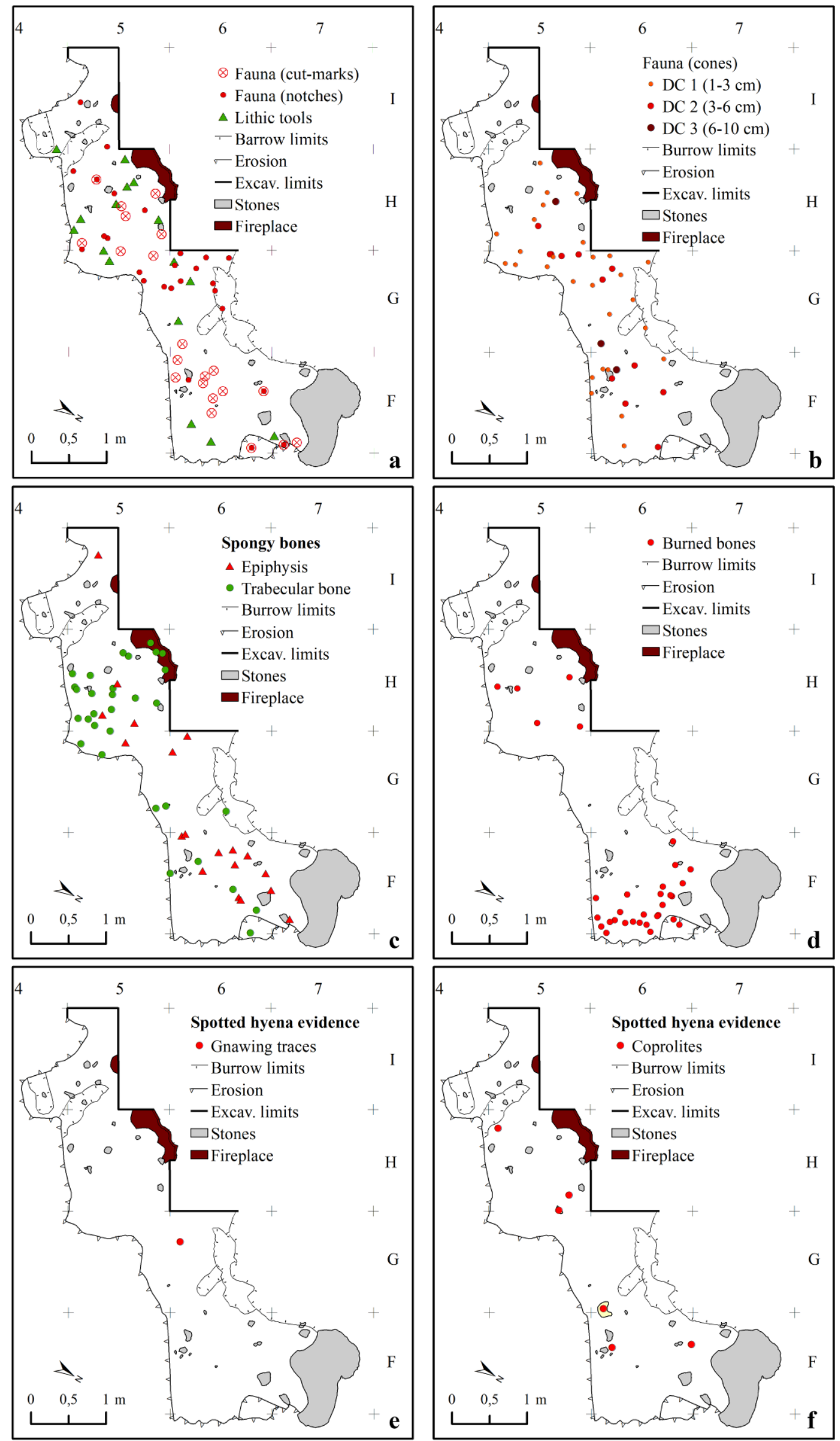
Fig. 13. Visual maps: a) correlation between lithic tools, faunal remains with cut-marks and/or Commented [13]: 1.5 column; Colour online only notches; b) cones sorted by dimensional classes; c) spongy bones sorted by epiphyses and by trabecular indeterminate bones; d) burned bones; e) bone with gnawing traces; f) coprolites. 

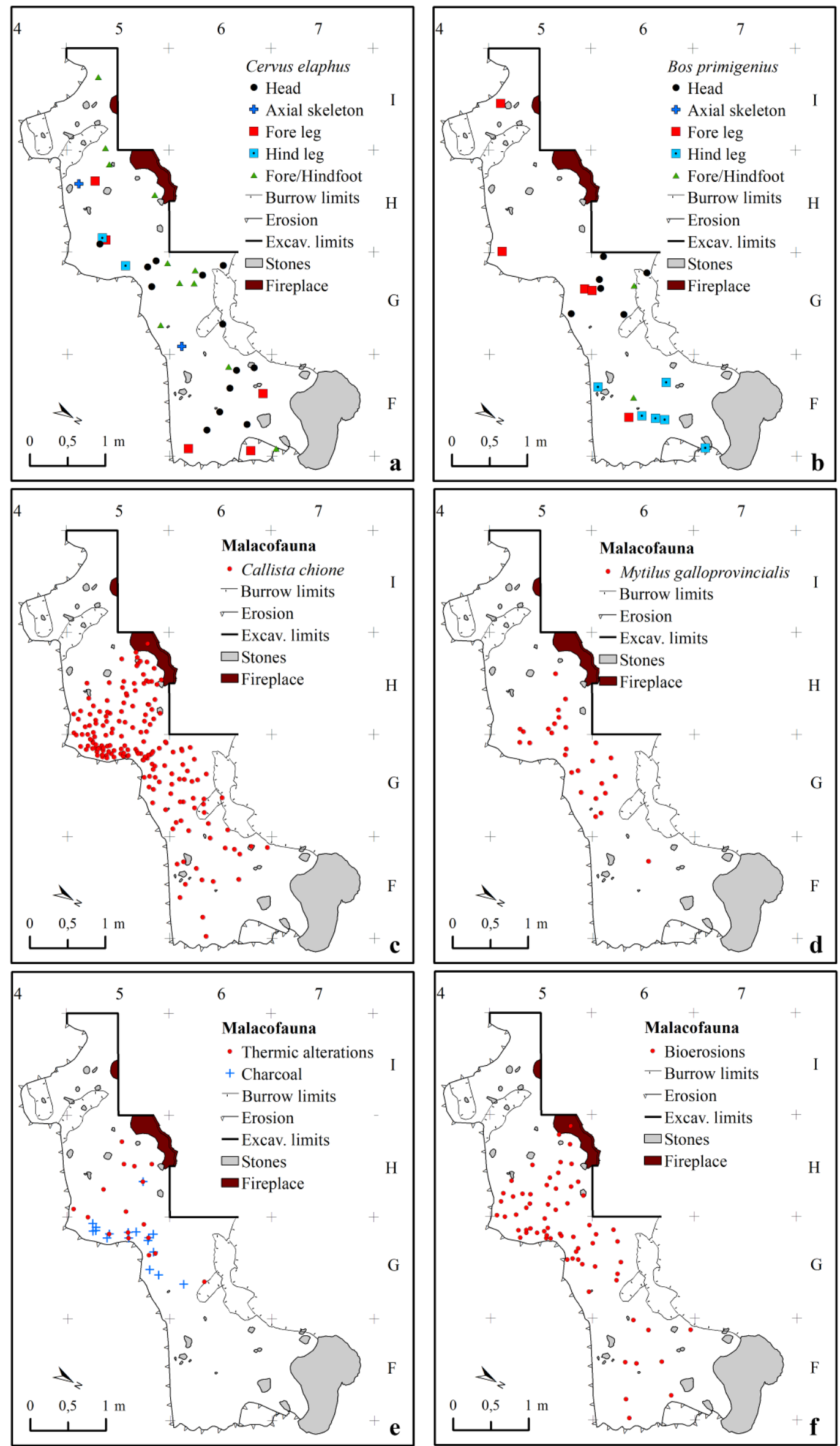
Fig. 14. Visual maps: a) distribution of Cervus elaphus; b) distribution of Bos primigenius; c) distribution of Callista chione; d) distribution of Mytilus galloprovincialis; e) malacofauna with thermic alterations and/or traces of charcoal; f) malacofauna with bio-erosions.

The scant hyena-related evidence (including the gnawed bone and the trampled and highly fragmented coprolites) do not exhibit evidence of clustering. Conversely, a higher spatial structure signal is detectable among the anthropogenic materials (Figs. 13-14). Interestingly, in G6/III, a fragment of a red deer ileum with cutmarks was found superimposed on a trampled coprolite.

\subsubsection{Spatial patterns and Neandertal behaviour}

Comparisons of results from both L(d) Ripley's function and visual maps returned clustered patterns among most of the analysed categories (e.g. spatial distribution of faunal remains with percussion-marks, cones, trabecular bones, burned bones, malacofauna and shells with thermal alterations and charcoal). Moreover, even if in the confidence envelopes of the L(d) Ripley's function, also the spatial distributions of lithic micro-debris, lithic tools and faunal remains with cut-marks resembles a clustered-type pattern (Figs. 11, 13-14, S2, S3).

Broadly speaking, a structured aspect of the studied area emerges both from the density/scatter maps and from the cluster analysis, the cophenetic correlation value $(c=0.8055)$ of which underlines the quality of the final dendrogram. The different clusters recognised are characterised by specific co-occurrences of findings. In particular, sectors I5-H5/IV and F7-F6/I, identified by cluster 4 , are characterised by a very low density of anthropogenic signal (Figs. 11, 13-15). On the contrary, higher concentrations of findings are recorded in other sectors. The distinctive feature of F6/II-III (corresponding to cluster 1) is the indirect evidence of fire (given by a concentration of burnt bones) (Figs. 13-15). The central part of the excavated area contains clusters 2 and 3. Small faunal remains (1-3 cm in length), cones and marine shells are common items in both these clusters. However they differ from one another for the larger concentration of large faunal remains ( $>10$ $\mathrm{cm}$ ), bones with impact notches, trabecular bones and lithic tools (cluster 2) and for a higher occurrence of bones with cut-marks (cluster 3) (Fig. 15). In agreement with the cluster analysis, the density/scatter maps emphasize the same pattern (Figs. 13-15). Finally, taking into consideration the spatial distribution of Cervus elaphus and Bos primigenius, which are the most abundant species in the faunal sample, we note that the former appears to be randomly distributed, whilst the latter, is markedly clustered, especially when we take into account its different anatomical parts: sector G5-G6 mainly includes head remains (two jaws and four isolated teeth) and forelegs; sector F6-F7 exclusively contains hind-legs (mainly tibia fragments) (Fig. 14a-b). 


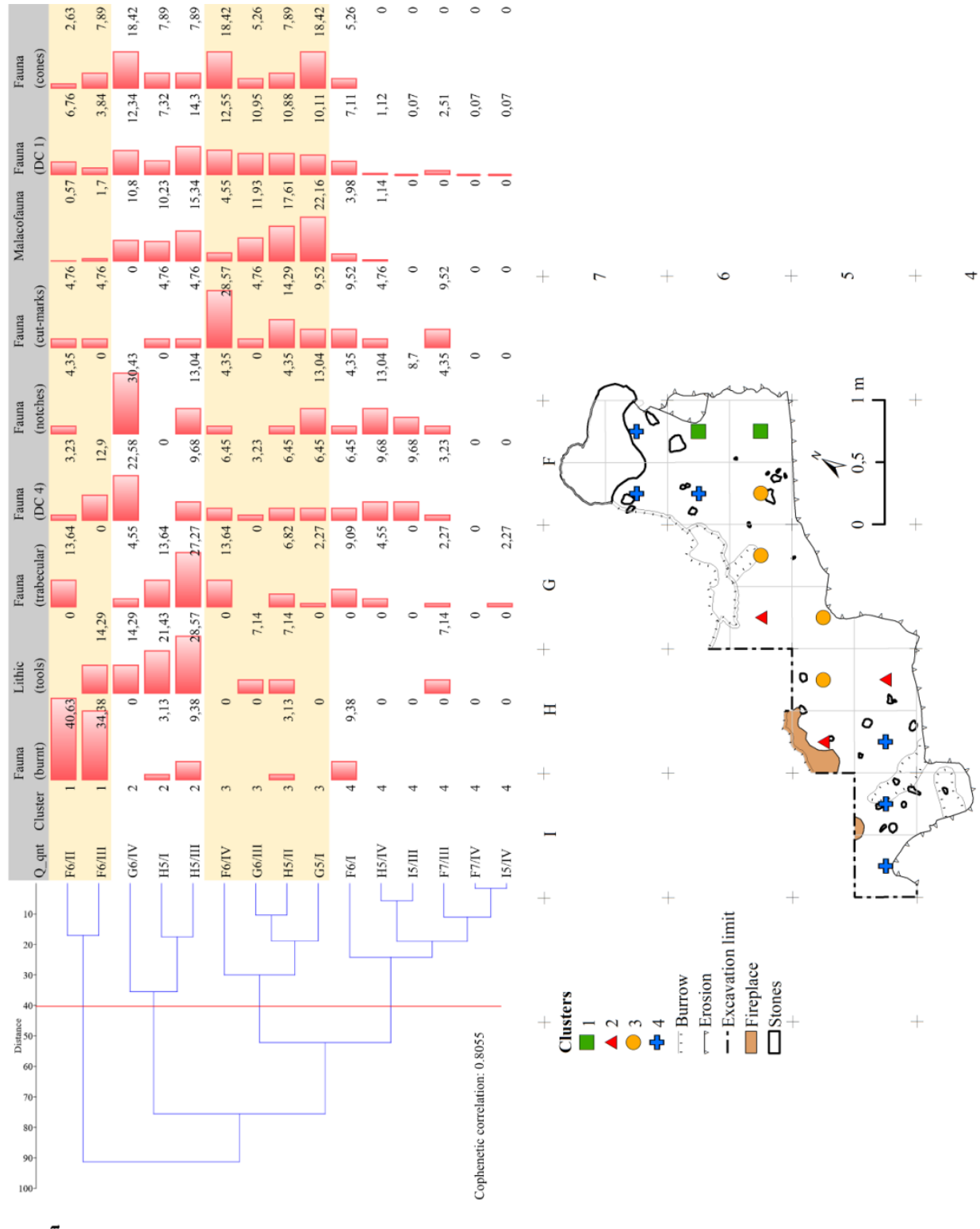

Fig. 15. Results of the Ward's Cluster Analysis (a: dendrogram and related table; b: spatial Commented [15]: Double column; Colour online distribution of identified clusters). 


\section{Discussion}

\subsection{Preservation of the context and Homo-Crocuta relationships}

The asymmetrical preservation of living floor $150 \mathrm{~A}$ is linked to the complex post-depositional history of the cave infill. The most destructive event that affected the deposit of Grotta dei Santi is the marine ingression due to the Holocene sea high-stand (Fig. 16). Taking into account both the changes of sea level and the regional tectonic stability (Antonioli, 2012; Ferranti et al., 2006; Waelbroeck et al., 2002), we know that, during the late Pleistocene, after the deposition of Unit 150, the sea-level was continuously lower than it is today and there was a wide plain extending in front of the cave during the Mousterian occupation. It is only with the Holocene that a relatively rapid rising of sea level has been recorded. This event led to the present landscape (isolating the entrance of the cave from the mainland) and removed the forepart of the prehistoric deposit. Such an erosional process is still active today as testified by the material signals due to some exceptional southerly gales (Moroni et al., 2019).

The presence of irregular channels crossing some parts of the deposit could be probably related to the action of small-to-middle sized mammals. Among these, the post-depositional wide burrow (possibly due to the action of a small carnivore/lagomorph den), which affected not only Unit 150 but also Unit 111, although highly destructive, is well delimited (Fig. 16).

Other taphonomic parameters appear to be more controversial and need a better contextualization to allow for correct interpretation.

The state of faunal remains (fresh aspect of surfaces, cut-marks and edges, absence or scarcity of trampling and vegetal/animal activity) and lithic finds (fresh edges, clear use-wear traces, very scant evidence of post-depositional alteration on the lithic edges), suggests a good preservation of the context (e.g. no prolongated exposition of materials to weathering and abrasive agents) (Behrensmeyer, 1978; Lyman, 1994:354-403). On the other hand, the molluscs seem to be framed within a different formational history than faunal remains and lithic finds. The relative difference in their physical state can be related to their fragility due to decalcification. The temporal relation between this decalcification/alteration process and their introduction into the site is not clear. The simultaneous presence of most altered shells and of some very well-preserved large specimens could be consistent with the introduction into the cave of both fresh and partially altered shells. The horizontality of the living floor in the excavated area, together with the planar fabric of the findings and the clustered patterns of most specimens, could suggest a good preservation of the Palaeolithic context and of its behavioural patterns. Nevertheless, the evidence of clusters of findings with a planar fabric on a horizontal layer is not exclusively determinant for assessing the preservation rate of the context, due to the equifinality problem. 
Other taphonomic parameters, such as the preservation state of the fireplace, the size-sorting and the fabric analyses, lead us to recognize evidence of a possible partial reworking of the context.

Different preservation patterns were recorded among the fireplaces of Grotta dei Santi (all surficial). The perfectly preserved structures are characterized by ash beds covering charcoal layers and thermally-altered sediments. In some cases, more phases of use are suggested given the interlayering of distinct ash-layers and thin brownish/reddish sands (rubefactions). Perfectly preserved fireplaces were excavated and documented in Unit 111; possible well-preserved fireplaces are visible in the cross-sections of Units 100, 150 (lower living floors) and 1004. Conversely, the set of badly-preserved fireplaces spans from the ones with only partially preserved ash layers to the those with almost completely destroyed features, testified by the rubefaction alone (as in the case of living floor 150A). The presence of these variegate preservation patterns must be analysed and contextualized more in-depth per Unit. Different agents could be responsible for the bad preservation of the fireplace of living floor 150A (e.g. trampling, low-energy water-flow, bioturbation and other post-depositional processes). The apparent small-scale dislocations between the items bearing evidence of exposition to fire/charcoal (faunal and malaco-faunal remains) and the fireplace could reaffirm the hypothesis of a low-energy shallow-flux event (with a WWS $\rightarrow$ EEN direction). However the limited extent of the excavated area imposes prudent interpretation. The quantitative distribution of lithic finds by Dimensional Classes highlights a significant underrepresentation of the smallest items (present anyhow in the lithic sample). The observed quantitative profile cannot be related to bias during the recovering phase, because the soft-sediment covering the living floor allowed for an accurate recovering of sieved findings (based on $1 \mathrm{~mm}$ wide mesh sieves). According to the theoretical size-distribution model of a knapping assemblage provided by Bertran et al. (2012), the quantitative profile of the lithic sample resembles wash material related to ultimate stages of residualization. Nevertheless, given the preliminary nature of this research, more data are needed to verify and calibrate this hypothesis. First, the absolute majority of smaller faunal remains $(1-3 \mathrm{~cm})$ partially contrasts with the evidence of lithic finds (despite the different criteria of size classification of faunal remains and lithics). Second, both the lithics and faunal remains do not return clear evidence of linear size-sorting and, so far, there are no sufficient data about the relief morphology of living floor 150A from unexcavated areas. Finally, the partiality and limited extent of the present day excavated area seriously hinders the formulation and verification of more specific hypotheses. Surely, the presence of micro-debris in the living floor 150A testifies that some in situ lithic knapping activities were carried out by the inhabitants. Nevertheless, only the identification of de facto refuses (sensu Schiffer, 1972) areas can tell us where these activities were carried out. Water-flow events can significantly undermine the preservation of such areas in the archaeological record, depending on the flow energy (e.g. Bertran 
et al., 2012; Isaac, 1967; Schick, 1986, 1987). The spatial pattern of the lithic micro-debris from living floor 150A seems to suggest two possible sorts of "disordered cluster". Both these zones seem to be related to the presence of fire, as suggested by the rubefaction of the sediment and the presence of burned malacofauna in square $\mathrm{H} 5$ and by the concentration of burned faunal remains in square F6/II-III. This evidence resembles the typical hearth-related assemblage model (sensu Binford, 1983), but the very low proportion of micro-debris is not compatible with an experimental lithic knapping assemblage (e.g. Bertran et al., 2012; Schick, 1986, 1987; Spagnolo et al., 2019 and reference therein). Consequently, unless the evidence from living floor 150A represents some marginal/peripheral scatters of drop-zones located elsewhere, these micro-debris weak clusters could be considered to be the remnants of partly residualized drop-zones, possibly by a kind of lowintensity shallow flow, like, for example, an overland flow (Bertran et al., 2012; García-Moreno et al., 2016; Isaac, 1967; Schick, 1986, 1987).

The anisotropic patterns identified among the elongated bones seem to be strongly sensitive both to the elongation index and to the spatial origin of the samples from the excavated area. The EI allows recognition of a trend evolving from the criss-crossed pattern of the bones with $1.7 \leq \mathrm{EI} \leq 2.5$ (NWSE vs SW-NE) towards the strongly iso-oriented pattern of remains with EI $\geq 3.5$ (SSW-NNE); the "intermediate" elongated specimens seem to follow both rules, with a dominant SW-NE mean vector, but statistically not supported. The SW-NE anisotropic orientation (dominant among the bones with $\mathrm{EI}>2.5$ and secondary among the ones with $\mathrm{EI} \leq 2.5$ ) is the same observed in squares H5-I5. The results of the orientation analysis are in line with ambiguous interpretations, in particular with the limited extent of the excavated area, due to the possible equifinality problem. As shown by experimental studies, statistically significant preferential orientations can be produced by a plethora of causes, including water flows, gravity, scuffing/trampling, human activities and, on a smaller scale, also stochastic events (Arriaza et al., 2018; Domínguez-Rodrigo et al., 2014; Eren et al., 2010; Frostick and Reid, 1983; Krajcarz and Krajcarz, 2014; Lenoble et al., 2008; Olsen and Shipman, 1988). The most plausible explanatory model fitting with the evidence from living floor $150 \mathrm{~A}$ seems to be the occurrence of an ephemeral post-depositional shallow flux of very low energy. This hypothesis is supported both by the significant (and complementary) difference of the observed patterns by elongation indexes and by the internal coherence of the dominant mean vectors (also in relation to the spatial criterion). As shown by experimental approaches the aligned patterns are typically a function of the morphology/a-axis of the re-oriented specimens, the energy of flux, the height of water and the substrate interaction. In general, a low energy shallow flux selectively re-orients the most elongated items transversally to the current and the specimens with a lower a-axis are re-oriented downstream. Partially submerged bones with high Elongation Indexes can be re-oriented parallel to the current only by increasing the water height (completely 
submerging the bones) and the flow energy. At the same weight/size of bones and hydrodynamic setting the specimens with lower EI (that means a shorter distance between the center of gravity of the bone and its extremities) offer minor resistance to the current (than the most elongated ones), reaching the equilibrium position parallel to the current earlier. This implies that the presence of EIrelated unimodal and/or "mixed" (e.g. criss-cross) patterns in the archaeological assemblage, can provide clues about the hydraulic conditions during its formation/burial (Domínguez-Rodrigo et al., 2012, 2014; Schick, 1986; Voorhies, 1969). Moreover, the different patterns by spatial criterion of elongated bones could be related to local difference in the flow energy. In the general frame of a shallow flux of low energy, a relatively higher energy is expected in H5-I5 (where clearly isooriented patterns are detected) and a relatively lower one (or almost absent) is expected in other sectors (where the hypothesized flux was not able to re-assort the elongated bones). Finally, the dominant a-axis orientations observed in the excavated area suggest a possible NW-SE current direction. This hypothesis of a shallow flux contextual to the sealing of living floor 150A appears also consistent with the sedimentological evidence from the upper Units of the stratigraphic sequence, suggesting that some water-flow events took place inside the cave, possibly related to cyclical, intensive and periodic rainfall (Moroni et al., 2019).

Summing up, limited to the excavated area, the global analysis of taphonomic parameters from living floor 150A of Grotta dei Santi (which taken individually appear at least ambiguous or with poor resolution) allows us to frame its burial into a well-defined formational framework. The bestfitting hypothesis that seems to satisfy all the taphonomic parameters implies a post-depositional shallow flux of low energy spatially characterized by relative intensity gradients (perhaps related to an intensive rainfall event). This event could had affected living floor 150A (possibly not far in time from the camp abandonment of Neandertals), influencing both its relative preservation degree and burial. More specifically, different grades of alteration of the systemic context are mirrored by the archaeological evidence. The inter-class gradients of preservation (e.g. size patterns of lithics and faunal remains, elongated bones orientation by EI, fireplace preservation) could be read in terms of specific "responses" of the different kinds of materials/features to the same taphonomic agent. The intra-class gradients (e.g. differences in orientation patterns of elongated faunal remains by spatial criterion) could be related to differences in the local intensity of taphonomic agents. These gradients imply different visibility grades of the residualized behavioural patterns. The thermal altered sediment in squares H5/I5 is the only direct clue recalling the original presence of a fireplace. Despite its ash and charcoal being totally washed away by the hypothesized water-flow (hindering an evaluation of the hearth "life"), the rubefaction allows us to recognize the actual position of the fireplace, thus returning a clear-cut datum. The higher fragility of surface fireplaces (e.g. absence of stone structures or pits) hinders the evaluation of "washing away" intensity. Data about the size- 
sorting of lithics and faunal remains and the orientation analyses of elongated bones are both consistent with a shallow flux of low energy (possibly with a WWS $\rightarrow$ EEN direction). This flow should be sufficient to produce incipient anisotropic patterns and to remove a part of the smallest lithic items (significantly underrepresented with respect to the larger dimensional classes). This low energy flow can be inferred from the incomplete anisotropy of elongated specimens (both in terms of Elongation Index and spatial sector), from the absence of upward size-based surviving trends of heavier materials (e.g. very high frequency of the smallest dimensional classes among faunal remains) and the absence of well-defined linear size-sorting of materials compatible with surficial water-flows. The presence of clustered and spatial segregated-like patterns among different classes of materials (not only the ones directly related to the taphonomic approach) suggests a possible partial preservation of some behavioural patterns in the residualized spatial arrangement of this living floor. Moreover, the perfect physical state of faunal remains and lithics suggests a relatively short-span of the exposition of these material to possible weathering/abrading agents. The possible relatively fast burial of archaeological materials could be contextual to the sediment transport/deposition dynamics produced by the hypothesized shallow flux in its final phase (perhaps soon after the camp-site abandonment of Neandertals) (Fig. 16). Finally, the most destructive postdepositional events that affected living floor 150A include the burrows and the Holocene erosion (Fig. 16). The former are not easily placeable in time, but surely, they formed after the deposition of Unit 111. Their impact on the living floor is high but exact, thus not representing a significant problem in terms of context integrity. On the other hand, this sea erosion caused the washing away of a significant part of the cave infill, seriously compromising the reconstruction of the whole camp spatial organization.

Given these premises, an isomorphic correspondence is expected to be found between the spatial patterns of the findings and the actual behaviours of their authors. In other words the systemic context should have suffered a relatively small-scale alteration, mainly due to a sub-synchronic involuntary action (the possible low energy shallow flux). In this scenario, some behaviourallyrelated associations of materials could still be found, allowing a more or less fuzzy recognition of activity areas and/or site structure (Fig. 16).

More telling, Neandertal camp 150A probably took place immediately after a brief hyena denning event (Fig. 16). This assumption is supported by the different weight and structuration of the hyenarelated and human-related evidence and by the stratigraphic overlapping of the ileum of red deer with cut-marks and the trampled coprolites in G6/III. The ephemeral evidence of carnivore activities contrasts with the typical pattern showed by Units with massive and/or exclusive presence of Crocuta crocuta, both at Grotta dei Santi (Moroni et al., 2015, 2019; Spagnolo et al., 2016b) and in other Pleistocene hyena dens (Arribas and Palmqvist, 1998; Conti et al., 2012; Crezzini et al., 
2016; Diedrich, 2010, 2011; Fourvel, 2012; Potts et al., 1988; Rusch et al. 2019; Saladié et al., 2017; Sanchis et al., 2019).

\subsection{Neandertal behaviour in living floor $150 \mathrm{~A}$ of Grotta dei Santi}

\subsubsection{Exploitation of faunal resources}

Despite the small size of the studied sample the analysis of macro-mammal remains from living floor 150A has provided important information about the exploitation of faunal resources by Neandertals of Grotta dei Santi. Hunting activities were focused on cervids and Bos primigenius. The most common anatomical parts transported into the site were head elements and limbs, while the axial skeleton was probably left at the killing sites. The absence of skeletal elements belonging to large carnivores (as for instance Crocuta crocuta and Panthera pardus which are recorded in other layers of the cave), together with the ephemeral presence of gnawing marks, corroborates the assumption that bone accumulation of $150 \mathrm{~A}$ was, mostly, if not exclusively, due to humans. The analysis of skeletal frequencies highlights the scarcity (phalanges and tarsal bones) / absence (sesamoids and carpal bones) of small bones, which are easily identifiable even when they are fragmented. Diaphysis portions are abundant, whereas epiphyseal parts are very few, both in the identified and in the unidentified sample. These results are perfectly consistent with the indications provided by other Mousterian sites located in Italy (Grotta Santa Croce: Boscato and Crezzini, 2007; Riparo 1'Oscurusciuto: Boscato and Crezzini, 2007, 2012; Spagnolo et al., 2016a; De Nadale Cave: Livraghi et al., in press), France (i.e. Abri du Maras: Daujeard et al., 2019; Grotte du Noisetier: Costamagno 2013; Costamagno and Rigaud, 2013; Les Pradelles: Costamagno and Rigaud, 2013) and Spain (i.e. Abric Romaní: Marín et al., 2019 and reference therein) and suggest the occurrence among different Neandertal groups a specific treatment of skeletal elements resulting in the lack of phalanges and spongy parts in the archaeological evidence.

\subsubsection{Lithic production and use}

In living floor $150 \mathrm{~A}$ the raw blocks introduced into the site were mainly local chert and radiolarite pebbles whose shapes were reduced differently according to the reduction concept: angular volumes for the additional unidirectional debitage, and lenticular pebbles for the Levallois. This capacity of taking advantage of the different shapes of pebbles in adapting manufacturing tactics to the specific nature of the raw material has been documented in other Middle Palaeolithic contexts which used pebbles as starting blocks, i.e. Riparo L'Oscurusciuto (Marciani, 2018) and Grotta Breuil (Kuhn, 1995). This idea of the initial selection of the starting block could have played an essential role in the economy of the raw material, i.e. the volume of the pebble allows the extraction of elongated supports from the first generation of strokes without the need to manage the lateral and distal 
convexities. Moreover, especially for the unipolar Levallois, the phase of initialisation of a block, which in this case coincides with the selection of the raw material, is a fundamental element for the definition of the Levallois as an integrated debitage concept (Boeda, 2013; Marciani, 2018). At Grotta dei Santi the local material was made up of small pebbles whose sizes impeded performing a real phase of management of the convexities. Thus the cores were depleted after one or two generations of removals. Consequently, the target flakes were researched from the beginning of the reduction sequence, also including the cortical flakes.

In addition, we note that some target and retouched flakes are larger than the other items of the collection. This evidence led us to hypothesise the importation of target items and retouched tools as already finished objects.

Despite the low number of lithic implements showing diagnostic use-wears, it is interesting to highlight the homogeneity in their use. All the items were employed in butchering activities, but only the pseudo-Levallois flake exhibits well-developed traces associable to this task. The elongated flakes, as said above, show weak traces interpreted as due to cutting fleshy tissues. Hafting or prehensive traces have not been detected on the lithic implements, but on the basis of the localisation of the use-wear we can reasonably suppose that the prehensile portion of the pseudoLevallois flake the part was the proximal one, whilst the prehensile part of the other flakes was the edge opposite to the active side prehension.

\subsubsection{Significance of the malacological results}

The malacological collection is composed of edible species, which are mainly interpreted as a food resource in several Mousterian contexts (e.g. Brown et al., 2011; Fa et al., 2016; Stiner, 1994; Stringer et al., 2008). Nevertheless, the possibility that molluscs of living floor 150A could be used for subsistence purposes should probably be rejected, at least in most cases. The presence of bioerosion on the ventral side of several shells and the occurrence of predation holes testify that Neandertals of Grotta dei Santi collected empty (and perhaps disarticulated) beached valves. The evidence of fire alterations on several specimens of $M$. galloprovincialis and C. chione seems rather owed to stochastic factors. Significantly, the localised thermal alterations on a large refitted valve of C. chione are clearly subsequent to the shell fragmentation, thus attesting to the unintentional nature of the exposition to fire (Fig. 10). In general, the heterogeneous and irregular distribution of the thermal traces is not consistent with a deliberate "cooking" of living molluscs. The concave shape of some wide shells could be related to a possible use as "containers" (e.g. Zilhão et al., 2010). However there is no clear evidence of this function. Also the occurrence of charcoal flecks inside some valves seems to be due to fortuitous contacts with charcoal scattered on the floor rather than to an intentional use of shells as containers of this material, as suggested by the localization patterns 
(both ventral and dorsal) of residues on the valves. However additional analyses aimed to identify possible contents, like organic compounds or mineral traces, are in agenda in order to clarify this issue.

Several studies have pointed out the effectiveness of the edges of some bivalves as a potential factor of their use as raw material for making tools. A number of Mousterian sites in Greece and Italy is characterized by the presence of scrapers made on valves of $C$. chione, some of which used in processing wood, hide and meat (Romagnoli et al., 2015, 2016, 2017). The exploitation of valves of C. chione as blanks for tools seems to be unknown at Grotta dei Santi, where no evidence of this kind has been detected so far (both in 150A and other layers).

The introduction in Palaeolithic contexts of some species of molluscs as unintentional by-products of beached kelp and sea-grass, collected for utilitarian purposes, including food, has been put forward by some scholars. Archeologically the only way to infer the occurrence of activities related to the collection of seaweed and/or sea-grasses by humans are the retrieval of small $(<2 \mathrm{~cm})$ nondietary shell middens (e.g. Ainis et al., 2014; Barrière, 1969; Colonese et al., 2011; Fa et al., 2016; Lubell et al., 2007; Mellars, 1996; Zilhão et al., 2010) or the preservation of micro-botanical evidence (Zilhão et al., 2010). The presence of very small shells unsuitable for being exploited for food or any other plausible use, could, perhaps, hint at a collection of benthic macrophytes by the Neandertals of living floor 150A.

The use of shells for ornamental purposes is reported in some Mousterian contexts (e.g. Peresani et al., 2013; Zilhão et al., 2010). Nevertheless, none of the species identified at Grotta dei Santi seem to have had an ornamental or symbolic interest for people living in the cave, as no evidence of clearly symbolic-related behaviours (e.g. engraving, piercing, colouring) has been identified within the mollusc sample.

\subsubsection{Activity areas and site-structure as inferred by spatial analysis}

Taphonomic considerations about the post-depositional events affecting living floor 150A allow us to focus on a critical question: the exact interpretation of the context from a spatial-functional standpoint on a limited study area. Given the limited extent of the currently available surface, it is too early to reconstruct a possible site structure. More data are needed for a better spatial-functional contextualization of living floor 150A, that will be the object of further research. Despite the partial reworking of this living floor, promising data are shown by the different spatial co-varying of finds correlated to specific behaviours (detected by Ward's cluster analysis, kernel density and distribution maps). As a general observation, the occurrence of segregated spaces, with specific cooccurrence of findings, is somehow detectable from the current evidence, suggesting possible multipurpose activity areas, probably corresponding to the so-called hearth-related activity areas 
model of L. Binford (1983), well documented in Mousterian sites (among others: Boscato and Ronchitelli, 2008; Bourguignon et al., 2002; Cremaschi et al. 2002; Cyrek et al., 2010; Gabucio et al., 2018; Henry, 2012; Lembo et al., 2012; Machado et al., 2013; Martínez-Moreno et al., 2016; Moreau and Locht, 2017; Neruda, 2017; Ortiz Nieto-Márquez and Baena Preysler, 2017; Plavšić, 2015; Real et al. 2018; Riel-Salvatore et al., 2013; Spagnolo et al. 2019, accepted; Speth et al., 2012; Valensi et al., 2013). 


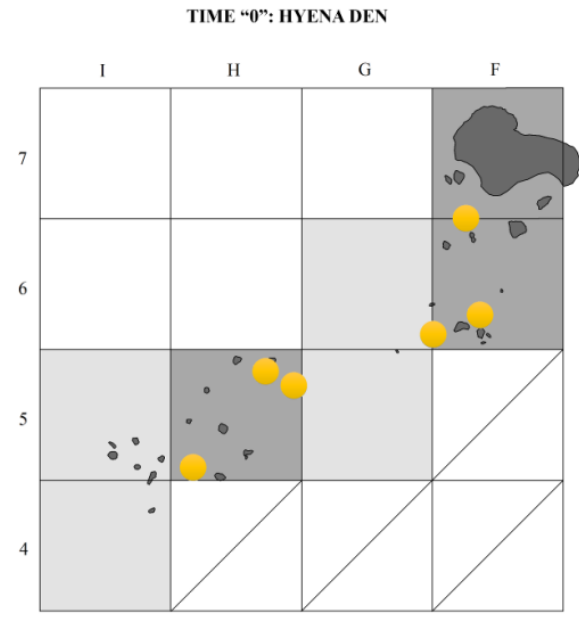

TIME "2": SHALLOW-FLUX OF LOW ENERGY
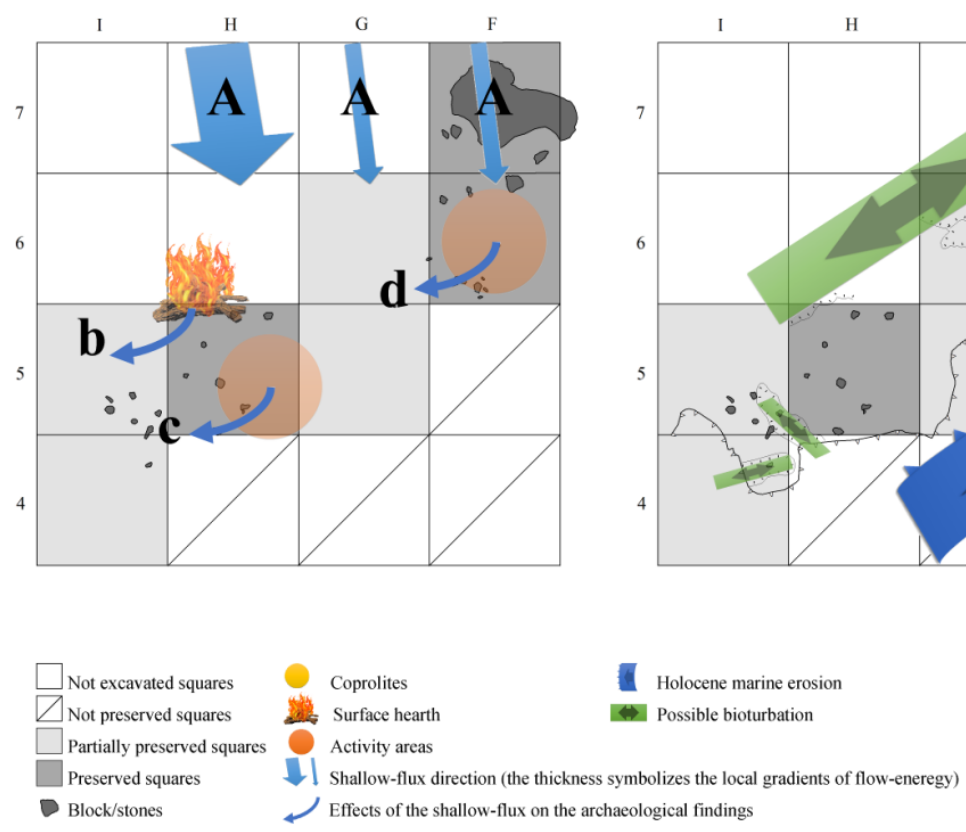

Fig. 16. Schematic representation of the processual history of living floor 150A. The first occupation corresponds to the hyena den (time 0 ): trampled and badly-preserved coprolites and a gnawed bone are the related clues. After this brief episode, the human occupation (time 1) follows shortly after, characterized by several multipurpose hearth-related activity areas (with evidence of faunal resource exploitation, stone tool manufacturing and, possibly, use of seagrass and/or shells).

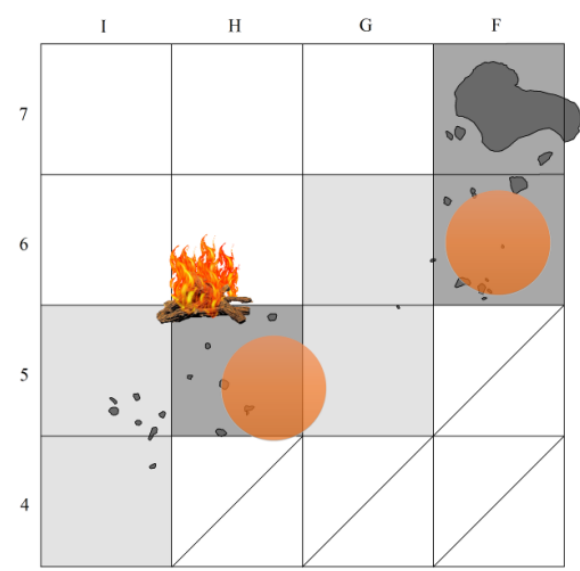

TIME "3": BIOTURBATIONS - MARINE EROSION

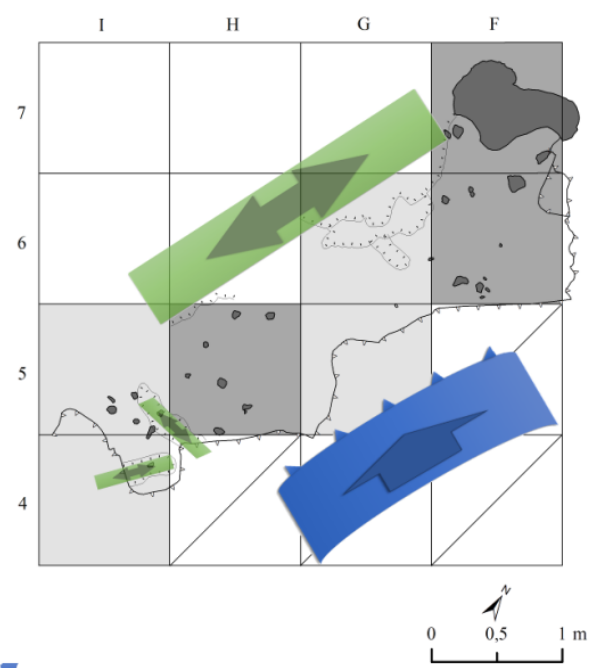

.


Subsequently (time 2), a shallow-flux of low energy (A) is documented (possibly with local intensity gradients), causing the hearth-ash removing (b), the partial dislocation of lithic microdebris with small-scale displacement of lighter materials $(c, d)$ and the anisotropic pattern of elongated bones (c) both parallel and transversal to the current. Finally (time 3), other more massive destruction of the deposit acted both to a small scale (as the possible mammal burrows) and to a large scale (the Holocene marine erosion). The first two steps (times 0-1) can be considered closely syn-depositional, the last step (time 3 ) post-depositional.

Interestingly, the different spatial patterns displayed by faunal remains by species allow us to hypothesize a possible temporal sequence: the red deer remains scattered around could be related to a previous exploitation. On the other hand, the clustered pattern of the auroch (by anatomical district also) could indicate that it was the last prey, butchered and exploited immediately before the group of Neandertals abandoned the cave (Fig. 14a-b).

This evidence, along with the apparent preservation of possible behaviourally-related spatial associations of materials, represents an additional clue for evaluating the living-floor integrity. From the temporal perspectivism (sensu Bailey, 2007) standpoint, both the presence of two overlapped and close in time occupations (referring the one to a hyena den and the other to a Neandertal camp) and the processual syn-depositional history of living floor 150A highlight the short-lived palimpsest nature sensu stricto of this level. The anthropogenic evidence from living floor 150A, seems to be linked, in effect, to a single occupation episode, whose brief duration appears to be particularly suitable for very-high-resolution analyses.

\section{Conclusions.}

The stratigraphic sequence of Grotta dei Santi is an irreplaceable archive for the reconstruction of multiple aspects linked to the palaeo-environmental history of the western area of Central Italy during the MIS 3. The opportunity of analysing high temporal resolution contexts with different preservation state and characterized by the presence of Neandertals and other predators (especially the spotted hyena), may contribute to creating a robust frame of reference for a taphonomic approach to the study of Pleistocene sites.

In particular, the evidence from living floor 150A enabled us to compare the taphonomic effects due to the chronologically very close use of the cave by spotted hyena and Neandertals on the one hand and to a subsequent taphonomic alteration agent on the other. Some of the spatial patterns identified are compatible with a shallow flux of low energy which affected this living floor immediately before its burial. This taphonomic agent seems to be locally characterized by different intensity grades, which produced small-scale displacements and partial re-orienting of some materials and 
removed the lighter features (like the fireplace ashes) and, probably, most of the lithic micro-debris. Nevertheless, some behaviourally-related spatial patterns appear to be preserved and detectable. These can be confidently attributed to human activity only. The different preservation and magnitude of the evidence related to the hyena and Neandertal occupations and the overlapping of a bone with cut-marks upon a trampled coprolite suggest that a brief hyena denning shortly preceded the arrival of Neandertals with their structured camp.

Despite the limited extent and partiality of the investigated area, multidisciplinary integrated analysis of data returned a picture of a Neandertal camp, documenting a variety of behavioural information.

The economy of lithic production includes the raw material acquisition phase, as shown by the interdependence between reduction concept and morphology of pebbles (angular volumes for the additional unidirectional debitage, lenticular for the Levallois), documenting the capacity of Neandertals to adapt their manufacturing tactics to the morpho-dimensional characters of the raw materials. Worthy of note is the possible co-presence of an in situ production (one/two-generations of target flakes from small pebbles) and the introduction of finished objects (larger target and retouched flakes). This evidence can provide possible clues for further contextualization of the mobility patterns.

When present, the use-wears seem to be very well-preserved, allowing us to identify multiple aspects related both to the ergonomics of the tools (prehensive/hafting portions) and to their actual use (butchering activities).

The analysis of faunal remains has been decisive in defining the relative roles of hyena and anthropogenic occupation patterns of living floor 150A (a predominant weight of anthropogenic evidence compared to that of the carnivore). In addition, the underrepresentation/absence of some skeletal elements (phalanges and spongy parts), attests to a specific treatment of these anatomical districts by Neandertals. Such evidence, which is documented in other Italian Mousterian sites as well as in the Middle Palaeolithic of France and Spain, opens up intriguing research perspectives about the functional (e.g. use of spongy parts as fuel, food, or other) and geographic/ecologic (e.g. punctuated traditions due to cultural convergence) meanings of this behaviour. Interestingly, the presence of marine shells in the cave offers the possibility of shedding light on some poorly documented aspects of Neandertal behaviour. Based on the taphonomic results, the hypothesis that, at Grotta dei Santi, these molluscs were used as food or for ornamental/symbolic purposes seems to be rejected. If the smallest specimens could be plausibly considered as byproducts introduced into the cave with beached benthic macrophytes (possibly used for subsistence or bedding purposes), the actual function of other species is still an open question. 
In living floor 150A, some possible co-varying patterns of behaviourally-related evidence could indicate the occurrence of sub-residualized latent activity areas. For instance, the redundancy of evidence related to butchering activities (e.g. homogeneity in the use of lithic tools documented by diagnostic use-wears, evidence of intensive exploitation of faunal resources, some spatial cooccurrence of butchering-related data) is a robust clue for inferring that this kind of activity took place in the internal part of the cave. The availability of a wider study-area will significantly improve our understanding of further possible functional destinations, perhaps at a higher spatial resolution.

The presence at Grotta dei Santi of several living floors (some of them apparently much better preserved than 150A) will give us the almost unique possibility of both performing high-resolution taphonomic studies and observing behaviour, social structure, economy, ecology and settlement dynamics by "facing Neandertals".

\section{Author contribution}

Until 2017 excavations at Grotta dei Santi were directed by Adriana Moroni in collaboration with Vincenzo Spagnolo, Giulia Capecchi, and Giulia Marciani. From 2018 Vincenzo Spagnolo took on the scientific direction of the excavations at the cave. Jacopo Crezzini and Francesco Boschin performed the zooarchaeological study. Giulia Marciani, in collaboration with Daniele Aureli carried out the lithic technological analysis and Simona Arrighi the use-wear study. Laura Tassoni analysed the malacofaunal sample. Isak Ekberg helped in inserting the faunal data into the geodatabase. Vincenzo Spagnolo conceptualized the paper, and performed the spatial analyses. All the authors collaborated in writing, reviewing and editing the final version of the paper.

\section{Acknowledgements}

We acknowledge the Soprintendenza Archeologia, Belle Arti e Paesaggio delle province di Siena, Arezzo e Grosseto. We are grateful to Corpo dei Vigili del Fuoco di Grosseto, Ufficio Circondariale Marittimo di Porto Santo Stefano, Ufficio Locale Marittimo di Porto Ercole, Accademia Mare Ambiente di Porto Santo Stefano, Argentario Divers di Porto Ercole, Croce Rossa di Porto Ercole, Associazione La Venta and AOG Industries di Luciano Chelli for logistic support. We are grateful to Comune di Monte Argentario, Banca di Credito Cooperativo di Castagneto Carducci, Rotary Club di Orbetello, Rotary Club di Monte Argentario and UniCoop Tirreno di Orbetello for financial support. Special thanks go to Enzo Bernabini, Andrea Bardi, Roberto Trapassi and all the firemen who took part in the fieldwork at Grotta dei Santi and to the commanders Ennio Aquilino, Mauro Caciolai, Massimo Nazareno Bonfatti and Giuseppe Del Brocco for their commitment and effort in 
facilitating the work and the stay in the cave of the research team. We are also grateful to people, students and researchers, who enthusiastically participated in various ways in the fieldwork at Grotta dei Santi and contributed to the achieved results. Many thanks to Claudia and Roberta Lepri for their help in getting financial support and to Prof. Geoff Phillips of the University of Pisa for helping with the English editing of the manuscript. Finally, we are grateful to the XVIII UISPP World Congress of Paris Committee and, in particular to the organizers of "Session XVI-3: Shortterm human occupations and mobility patterns", for giving us the opportunity of sharing our results and enlarging our scientific network. Finally we would like to sincerely acknowledge the two anonymous reviewers who really enriched the quality of this paper thanks to their valuable and interesting comments.

\section{References.}

Ainis, A.F., Vellanoweth, R.L., Lapena, Q.G., Thornber, C.S., 2014. Using non-dietary gastropods in coastal shell middens to infer kelp and seagrass harvesting and palaeoenvironmental conditions. Journal of Archaeological Science, 49, 343-360. https://doi.org/10.1016/j.jas.2014.05.024.

Antonioli, F., 2012. Sea level change in western-central Mediterranean since 300 kyr: comparing global sea level curves with observed data. Alpine and Mediterranean Quaternary 25 (1), 15-23.

Arriaza, M. C., Organista, E., Yravedra, J., Santonja, M., Baquedano, E., Domínguez-Rodrigo, M., 2018. Striped hyenas as bone modifiers in dual human-to-carnivore experimental models.

Archaeological and Anthropological Sciences, 1-13. https://doi.org/10.1007/s12520-018-0747-y.

Arribas, A., Palmqvist, P. 1998. Taphonomy and palaeoecology of an assemblage of large mammals: hyaenid activity in the Lower Pleistocene site at Venta Micena (Orce, Guadix-Baza, Granada, Spain). Geobios, 31 (3, supplément), 3-47. https://doi.org/10.1016/S0016-6995(98)80056$\underline{9}$.

Arrighi, S., Borgia, V., 2009. Surface modifications of flint tools and their functional meaning. Materials and Manufacturing Processes, 24, 922-927. https://doi.org/10.1080/10426910902987150. Baddeley, A., Rubak, E., Turner, R., 2015. Spatial point patterns: methodology and applications with R. Chapman and Hall/CRC. 810 p.

Bailey, G. N., 2007. Time perspectives, palimpsests and the archaeology of time. Journal of Anthropological Archaeology, Vol. 26, 198-223. http://dx.doi.org/10.1016/j.jaa.2006.08.002. 
Bargalló, A., Gabucio, M. J., Rivals, F., 2016. Puzzling out a palimpsest: testing an interdisciplinary study in level O of Abric Romaní. Quaternary International, 417, 51-65.

https://doi.org/10.1016/j.quaint.2015.09.066.

Barrière, J., 1969. Les coquilles marines découvertes sur le sol de la cabane acheuléenne du Lazaret. In: de Lumley, H. (ed.), Une cabane Acheuléenne dans la Grotte du Lazaret (Nice). Mémoires de la Société Préhistorique Française, Tome 7, pp. 117-118.

Behrensmeyer, A.K., 1978. Taphonomic and ecologic information from bone weathering. Paleobiology, 4 (2), 150-162.

Benito-Calvo, A., de la Torre, I., 2011. Analysis of orientation patterns in Olduvai Bed I assemblages using GIS techniques: implications for site formation processes. Journal of Human Evolution, 61, 50-60. http://dx.doi.org/10.1016/j.jhevol.2011.02.011.

Bertran, P., Lenoble, A., Todisco, D., Desrosiers, P. M., Sørensen, M., 2012. Particle size distribution of lithic assemblages and taphonomy of Palaeolithic sites. Journal of Archaeological Science, 39 (10), 3148-3166. https://doi.org/10.1016/j.jas.2012.04.055.

Bertran, P., Beauval, C., Boulogne, S., Brenet, M., Costamagno, S., Feuillet, Th., Laroulandie, V., Lenoble, A., Malaurent, Ph., Mallye, J. B., 2015. Experimental archaeology in a mid-latitude periglacial context: insight into site formation and taphonomic processes. Journal of Archaeological Science, 57, 283-301. http://dx.doi.org/10.1016/j.jas.2015.02.039.

Binford, L. R., 1983. In Pursuit of the Past. Decoding the Archaeological Record. Thames \& Hudson Ltd, London.

Binford, L.R., Mills, M.G.L., Stone, N.M., 1988. Hyaena scavenging behaviour and its implications for the interpretation of faunal assemblages from FLK 22 (the Zinj Floor) at Olduvai Gorge. Journal of Anthropological Archaeology, 7, 99-135. https://doi.org/10.1016/0278-4165(88)90011-6.

Blasco, R., Rosell, J., Sañudo, P., Gopher, A., Barkai, R., 2016. What happens around a fire: faunal processing sequences and spatial distributions at Qesem Cave (300 ka), Israel. Quaternary International, 398, 190-209. http://dx.doi.org/10.1016/j.quaint.2015.04.031.

Boëda, E., 1994. Le concept Levallois: variabilité des méthodes, Archéo édi. ed. CNRS, Paris. Boëda, E., 1997. Technogenèse de systèmes de production lithique au Paléolithique inférieur et moyen en Europe occidentale et au Proche-Orient. Université Paris Ouest Nanterre La Défense, Nanterre. 
Boëda, E., 2013. Techno-logique \& Technologie: Une paléo-histoire des objets lithiques tranchants. @ rchéo-éditions.

Bordes, F., 1961. Typologie du Paléololithique ancien et moyen. Mémoires de l'Institut Préhistorique de l’Université de Bordeaux.

Boscato P., Crezzini J. 2007. The exploitation of ungulate bones in Homo neanderthalensis and Homo sapiens. Human Evolution, 21, 311-320.

Boscato P., Crezzini J., 2012. Middle-Upper Palaeolithic transition in Southern Italy: Uluzzian macromammals from Grotta del Cavallo (Apulia). Quaternary International, 252, 90-98, http://dx.doi.org/10.1016/j.quaint.2011.03.028.

Boscato, P., Ronchitelli, A., 2008. Strutture di combustione in depositi del Paleolitico medio del Sud Italia, Atti del XVII Congresso dell'Associazione Antropologica Italiana, Springer, New York, pp. 218-225.

Boschian, G., Saccà, D., 2010. Ambiguities in human and elephant interactions? Stories of bones, sand and water from Castel di Guido (Italy). Quaternary International, 214, 3-16.

http://dx.doi.org/10.1016/j.quaint.2009.10.016.

Bountalis, A.C., Kuhn, B.F, 2014. Cave usage by multiple taphonomic agents: Issues towards interpreting the fossil bearing cave deposits in South Africa. American Journal of Zoological Research, 2 (4), 55-61. http://dx.doi.org/10.12691/ajzr-2-4-1.

Bourguignon, L., Sellami, F., Deloze, V., Sellier-Segard, N., Beyries, S., Emery-Barbier, A., 2002. L’habitat moustérien de «La Folie» (Poitiers, Vienne): synthése des premiers résultats. Paléo, 14, 29-48.

Brown, K., Fa, D.A., Finlayson, G., Finlayson, C., 2011. Small game and marine resource exploitation by Neanderthals: the evidence from Gibraltar. In: Bicho N.F., Haws J.A., Davis L.G. (Eds.), Trekking the shore: Changing coastlines and the antiquity of coastal settlement. Springer Science \& Business Media, New York, NY. pp. 247-272.

Camarós, E., Cueto, M., Teira, L.C., Tapia J., Cubas, M., Blasco, R., Rosell, J., Rivals, F., 2013. Large carnivores as taphonomic agents of space modification: an experimental approach with archaeological implications. Journal of Archaeological Science, 40 (2), 1361-1368.

http://dx.doi.org/10.1016/j.jas.2012.09.037. 
Camarós, E., Cueto, M., Teira, L., Münzel, S. C., Plassard, F., Arias, P., Rivals, F., 2017. Bears in the scene: Pleistocene complex interactions with implications concerning the study of Neanderthal behavior. Quaternary International, 435, 237-246. https://doi.org/10.1016/j.quaint.2015.11.027.

Carrer, F., 2017. Interpreting intra-site spatial patterns in seasonal contexts: an ethnographical case study from the Western Alps. Journal of Archaeological Method and Theory, 24 (2), 303-327. https://doi.org/10.1007/s10816-015-9268-5.

Chaplin, R. E., 1971. The study of animal bones from archaeological Sites. Seminar Press, New York.

Claassen, C., 1998. Shells. Cambridge University Press, Cambridge, UK.

Cobo-Sánchez, L., Aramendi, J., Domínguez-Rodrigo, M., 2014. Orientation patterns of wildebeest bones on the lake Masek floodplain (Serengeti, Tanzania) and their relevance to interpret anisotropy in the Olduvai lacustrine floodplain. Quaternary International, 322-323, 277-284.

http://dx.doi.org/10.1016/j.quaint.2013.07.130.

Colonese, A.C., Mannino, M.A., Bar-Yosef Mayer, D.E., Fa, D.A., Finlayson, J.C., Lubell, D., Stiner, M.C., 2011. Marine mollusc exploitation in Mediterranean prehistory: An overview. Quaternary International, 239, 86-103. https://doi.org/10.1016/j.quaint.2010.09.001.

Conolly, J., Lake, M., 2006. Geographical Information System in archaeology, Cambridge University Press, Cambridge.

Conti, N., Coppola, D., Petronio, C., Petrucci, M., Sardella, R., Salari, L., 2012. La fauna del Pleistocene superiore di Tana delle Iene (Ceglie Messapica, Brindisi, Italia meridionale). Bollettino del Museo Civico di Storia Naturale di Verona, 36, 63-76.

Costamagno, S., 2013. Bone grease rendering in Mousterian contexts: the case of Noisetier cave (Fréchet-Aure, Hautes-Pyrénées, France). In: Clark, J.L., Speth, J.D. (Eds.), Zooarchaeology and modern human origins. Springer, Dordrecht. pp. 209-225.

Costamagno, S., Rigaud, J.Ph., 2013. L’exploitation de la graisse au Paléolithique. Actes du 138e Congrès national des sociétés historiques et scientifiques, Apr 2013, Rennes, France. pp.134-152. Crema, E.R., Bianchi, E., 2013. Looking for patterns in the noise: Non-site spatial-analysis in Sebkha Kelbia. In: Mulazzani S (Ed.) Le Capsien de hergla (Tunisie). Culture, environnement et économie. pp. 385-395. Frankfurt:Africa Magna Verlag. 
Cremaschi, M., Peresani, M., Pizziolo, G., 2002. Analisi spaziale del suolo d'abitato musteriano BR6BASE della Grotta di Fumane. In: Peretto, C. (Ed.), Analisi informatizzata e trattamento dati delle strutture di abitato di età preistorica e protostorica in Italia, Origines, Firenze, pp. 58-70.

Crezzini, J., Boscato, P., Ricci, S., Ronchitelli, A., Spagnolo, V., Boschin, F., 2016. A spotted hyaena den in the Middle Palaeolithic of Grotta Paglicci (Gargano promontory, Apulia, Southern Italy). Archaeological and Anthropological Sciences, 8, 227-240. http://dx.doi.org/10.1007/s12520015-0273-0.

Cyrek, K., Socha, P., Stefaniak, K., Madeyska, T., Mirosław-Grabowska, J., Sudoł, M., Czyżewski, L., 2010. Palaeolithic of Biśnik Cave (Southern Poland) within the environmental background. Quaternary International, 220, (1-2), 5-30. https://doi.org/10.1016/j.quaint.2009.09.014.

Daujeard, C., Abrams, G., Germonpré, M., Le Pape, J.M., Wampach, A., Di Modica, K., Moncel, M.H., 2016. Neanderthal and animal karstic occupations from southern Belgium and south-eastern France: Regional or common features?. Quaternary International, 411, 179-197.

http://dx.doi.org/10.1016/j.quaint.2016.02.009.

Daujeard, C., Vettese, D., Britton, K., Béarez, P., Boulbes, N., Crégut-Bonnoure, E., Desclaux, E., Lateur, N., Pike-Tay, A., Rivals, F., Allué, E., Chacón, M.G., Puaud, S., Richard, M., Courty, M.A., Gallotti, R., Hardy, B., Bahain, J.J., Falguères, C., Pons-Branchu, E., Valladas, H., Moncel, M.H., 2019. Neanderthal selective hunting of reindeer? The case study of Abri du Maras (south-eastern France). Archaeological and Anthropological Sciences, 11 (3), 985-1011.

https://doi.org/10.1007/s12520-017-0580-8.

Dauvois, M., 1976. Precis de dessin dynamique et structural des industries lithiques prehistoriques. P. Fanlac, Paris.

Diedrich, C. G., 2010. Specialized horse killers in Europe: Foetal horse remains in the Late Pleistocene Srbsko Chlum-Komín Cave hyaena den in the Bohemian Karst (Czech Republic) and actualistic comparisons to modern African spotted hyaenas as zebra hunters. Quaternary International, 220, 174-187. https://doi.org/10.1016/j.quaint.2010.01.023.

Diedrich, C. G., 2011. The Crocuta crocuta spelaea (Goldfuss 1823) population and its prey from the Late Pleistocene Teufelskammer Cave hyena den besides the famous Paleolithic Neandertal Cave (NRW, NW Germany). Historical Biology, 23 (2-3), 237-270.

http://dx.doi.org/10.1080/08912963.2010.530348. 
Domínguez-Rodrigo, M., García-Pérez, A., 2013. Testing the accuracy of different A-axis types for measuring the orientation of bones in the archaeological record. Plos One, 8, e68955.

http://dx.doi.org/10.1371/journal.pone.0068955.

Domínguez-Rodrigo, M., Bunn, H.T., Pickering, T.R., Mabulla, A.Z.P., Musiba, C.M., Baquedano, E., Ashley, G.M., Diez-Martin, F., Santonja, M., Uribelarrea, D., Barba, R., Yravedra, J., Barboni, D., Arriaza, C., Gidna, A., 2012. Autochthony and orientation patterns in Olduvai Bed I: a reexamination of the status of postdepositional biasing of archaeological assemblages from FLK North (FLKN). Journal of Archaeological Science, 39, 2116-2127.

http://dx.doi.org/10.1016/j.jas.2012.02.027.

Domínguez-Rodrigo, M., Uribelarrea, D., Santonja, M., Bunn, H.T., García-Pérez, A., PérezGonzález, A., Panera, J., Rubio-Jara, S., Mabulla, A., Baquedano, E., Yravedra, J., Díez-Martín, F., 2014. Autochthonous anisotropy of archaeological materials by the action of water: experimental and archaeological reassessment of the orientation patterns at the Olduvai sites. Journal of Archaeological Science, 41, 44-68. http://dx.doi.org/10.1016/j.jas.2013.07.025.

Domínguez-Rodrigo, M., Cobo-Sánchez, L., Yravedra, J., Uribelarrea, D., Arriaza, C., Organista, E., Baquedano, E. 2018. Fluvial spatial taphonomy: a new method for the study of post-depositional processes. Archaeological and Anthropological Sciences 10, 1769-1789.

http://dx.doi.org/10.1007/s12520-017-0497-2.

Enloe, J. G., 2012. Middle Palaeolithic Cave Taphonomy: Discerning Humans from Hyenas at Arcy-sur-Cure, France. International Journal of Osteoarchaeology, 22 (5), 591-602.

http://dx.doi.org/10.1002/oa.1276.

Eren, M. I., Durant, A., Neudorf, Ch., Haslam, M., Shipton, C., Bora, J., Korisettar, R., Petraglia, M., 2010. Experimental examination of animal trampling effects on artifact movement in dry and water saturated substrates: a test case from South India. Journal of Archaeological Science, 37 , 3010-3021. http://dx.doi.org/10.1016/j.jas.2010.06.024.

Esteban-Nadal, M., 2012. Can Archaeozoology and Taphonomy contribute to knowledge of the feeding habits of the Iberian wolf? Journal of Archaeological Science, 39, 3208-3216. http://dx.doi.org/10.1016/j.jas.2012.05.004.

Fa, D.A., Finlayson, J.C., Finlayson, G., Giles-Pacheco, F., Rodríguez-Vidal, J., Gutiérrez-López, J.M., 2016. Marine mollusc exploitation as evidenced by the Gorham's Cave (Gibraltar) excavations 1998-2005: The Middle-Upper Palaeolithic transition. Quaternary International, 407 (B), 16-28. https://doi.org/10.1016/j.quaint.2015.11.148. 
Ferranti, L., Antonioli, F., Mauz, B., Amorosi, A., Dai Pra, G., Mastronuzzi, G., Monaco, C., Orrù, P., Pappalardo, M., Radtke, U., Renda, P., Romano, P., Sansò, P., Verrubbi, V., 2006. Markers of the last interglacial sea-level high stand along the coast of Italy: Tectonic implications. Quaternary International, 145-146, 30-54. https://doi.org/10.1016/j.quaint.2005.07.009.

Fourvel, J.-B., 2012. Hyénidés modernes et fossiles d'Europe et d'Afrique: taphonomie comparée de leurs assemblages osseux. Ph.D. Thesis, Université Toulouse le Mirail - Toulouse II

Frahm, E., Tryon, C.A., 2018. Origins of Epipalaeolithic obsidian artifacts from Garrod's excavations at Zarzi cave in the Zagros foothills of Iraq. Journal of Archaeological Science: Reports, 21, 472-485. https://doi.org/10.1016/j.jasrep.2018.08.001.

Frostick, L., Reid, I., 1983. Taphonomic significance of subaerial transport of vertebrate fossils on steep sub-arid slopes. Lethaia, 16, 157-164.

Gabucio, M.J., Fernández-Laso, M.C., Rosell, J., 2018. Turning a rock shelter into a home. Neanderthal use of space in Abric Romaní levels M and O. Historical Biology, 30 (6), 743-766. https://doi.org/10.1080/08912963.2017.1340470.

García-Moreno, A., Smith, G. M., Kindler, L., Pop, E., Roebroeks, W., Gaudzinski-Windheuser, S., Klinkenberg, V., 2016. Evaluating the incidence of hydrological processes during site formation through orientation analysis. A case study of the middle Palaeolithic Lakeland site of NeumarkNord 2 (Germany). Journal of Archaeological Science: Reports, 6, 82-93.

http://dx.doi.org/10.1016/j.jasrep.2016.01.023.

Geneste, J., 1991. Systèmes techniques de production lithique: variations techno-économiques dans le processus de réalisation des outillages paléolithiques. Techiques \& Cultures, 17-18, 1-36. https://doi.org/10.4000/tc.5013.

Grayson, D.K., 1984. Quantitative Zooarchaeology: Topics in the Analysis of Archaeological Faunas. Academic Press, Orlando.

Giusti, D., Arzarello, M., 2016. The need for a taphonomic perspective in spatial analysis: Formation processes at the Early Pleistocene site of Pirro Nord (P13), Apricena, Italy. Journal of Archaeological Science: Reports, 8, 235-249. http://dx.doi.org/10.1016/j.jasrep.2016.06.014.

Giusti, D., Tourloukis, V., Konidaris, G., Thompson, N., Karkanas, P., Panagopoulou, E., Harvati, K., 2018. Beyond maps: patterns of formation processes at the Middle Pleistocene open-air site of Marathousa 1, Megalopolis Basin, Greece. Quaternary International, 497, 137-153.

https://doi.org/10.1016/j.quaint.2018.01.041. 
Guilbaud, M., Carpentier, G., 1995. Un remontage exceptionnel à Tourville-la-Rivière (SeineMaritime). Bulletin de la Société Préhistorique Française, 92, 289-295.

https://doi.org/10.3406/bspf.1995.10029.

Gutiérrez-Zugasti, I., 2011. Shell fragmentation as a tool for quantification and identification of taphonomic processes in archaeomalacogical analysis: The case of the Cantabrian Region (Northern Spain). Archaeometry, 53 (3), 614-630. https://doi.org/10.1111/j.1475-4754.2010.00561.x.

Henry, D., 2012. The palimpsest problem, hearth pattern analysis, and Middle Paleolithic site structure. Quaternary International, 247, 246-266. http://dx.doi.org/10.1016/j.quaint.2010.10.013. Inizan, M., Ballinger, M., Roche, H., Tixier, J., 1999. Technology and Terminology of Knapped Stone. CREP, Nanterre.

Isaac, G.L., 1967. Towards the interpretation of occupation debris: some experiments and observations. Kroeber Anthropological Society Papers, 37, 31-57.

Keeley, L.H., 1980. Experimental Determination of Stone Tool Uses: a Microwear Analysis. Chicago-London, University of Chicago Press.

Krajcarz, M., Krajcarz, M. T., 2014. The Red Fox (Vulpes vulpes) as an accumulator of bones in cave-like environments. International Journal of Osteoarchaeology, 24 (4), 459-475.

http://dx.doi.org/10.1002/oa.2233.

Kuhn, S., 1995. Mousterian Lithic Technology: An Ecological Perspective, Princeton University Press, Princeton.

Kuhn, B.F., 2014. Short communication: A preliminary assessment of the carnivore community outside Johannesburg, South Africa. South African Journal of Wildlife Research, 44 (1), 95-98.

Laplace, G., 1964. Essai de typologie systématique, Annali dell’Università di Ferrara. Sezione XV: Paleontologia Umana e Paletnologia - Volume I, Supplemento II.

Laplace, G. 1968. Récherches de typologie analytique, Origini, 2, 7-63.

Leierer, L., Jambrina-Enríquez, M., Herrera-Herrera, A.V., Connolly, R., Hernández, C.M., Galván, B., Mallol, C., 2019. Insights into the timing, intensity and natural setting of Neanderthal occupation from the geoarchaeological study of combustion structures: A micromorphological and biomarker investigation of El Salt, unit Xb, Alcoy, Spain. PloS one, 14(4):e0214955.

https://doi.org/10.1371/journal.pone.0214955. 
Lembo, G., Bertolini, M., Peretto, C., Rufo, E., Thun Hohenstein, U., 2012. Analisi spaziali dei reperti faunistici e litici dell'US 5. In: Peretto, C. (Ed.), L'insediamento musteriano di Grotta Reali. Rocchetta a Volturno, Molise, Italia. Museologia Scientifica e Naturalistica 8/2, pp. 133-141.

Lenoble, A., Bertran, P., 2004. Fabric of Palaeolithic levels: methods and implications for site formation processes. Journal of Archaeological Science, 31, 457-469.

http://dx.doi.org/10.1016/j.jas.2003.09.013.

Lenoble, A., Bertran, P., Lacrampe, F., 2008. Solifluction-induced modifications of archaeological levels: simulation based on experimental data from a modern periglacial slope and application to French Palaeolithic sites. Journal of Archaeological Science, 35, 99-110.

http://dx.doi.org/10.1016/j.jas.2007.02.011.

Livraghi, A., Fanfarillo, G., Dal Colle, M., Romandini, M., Peresani, M., 2019. Neanderthal ecology and the exploitation of cervids and bovids at the onset of MIS4: a study on De Nadale cave, Italy. Quaternary International. https://doi.org/10.1016/j.quaint.2019.11.024.

Lubell, D., Jackes, M., Sheppard, P., Rowley-Conwy, P., 2007. The Mesolithic-Neolithic in the Alentejo: archaeological investigations, 1984-1986. In IV Congresso de Arqueologia Peninsular. From the Mediterranean Basin to the Portuguese Atlantic Shore: Papers in Honor of Anthony Marks: Promontoria Monográfia, 7, 209-230.

Lyman, R.L., 1994. Vertebrate taphonomy. Cambridge University Press, Cambridge.

Machado J., Hernández M., Mallol C., Galván B., 2013. Lithic production, site formation and Middle Palaeolithic palimpsest analysis: in search of human occupation episodes at Abric del Pastor stratigraphic unit IV (Alicante, Spain). Journal of Archaeological Science, 40 (5), 2254-2273. https://doi.org/10.1016/i.jas.2013.01.002.

Machado J., Pérez L., 2016. Temporal frameworks to approach human behavior concealed in Middle Palaeolithic palimpsests: A high-resolution example from El Salt Stratigraphic Unit X (Alicante, Spain). Quaternary International, 417, 66-81.

http://dx.doi.org/10.1016/j.quaint.2015.11.050.

Marciani, G., 2013. The lithic assemblage of the US 13 at the Middle Paleolithic site of Oscurusciuto (Ginosa, Taranto, Southern Italy): Technological studies. MA Thesis. Instituto Politécnico de Tomar. Universidade de Trás-os-Montes e Alto Douro. 
Marciani, G., 2018. Continuities and discontinuities during the late Middle Palaeolithic at the Oscurusciuto rock shelter (southern Italy). An integrated study of lithic manufacture in the strata SU 15, SU 14, SU 13 and SU 11. Ph.D. Dissertation. Universitat Rovira i Virgili, Tarragona, Spain.

Marciani, G., Spagnolo, V., Aureli, D., Ranaldo, F., Boscato, P., Ronchitelli, A., 2016. Middle Palaeolithic technical behaviour: Material import- export and Levallois production at the SU 13 of Oscurusciuto rock shelter, Southern Italy. Journal of Lithic Studies, 3, 1-24.

https://doi.org/10.2218/j1s.v3i2.1414.

Marín, J., Rodríguez-Hidalgo, A., Vallverdú, J., Gómez de Soler, B., Rivals, F., Rabuñal, J.R., Pineda, A., Chacón, M.G., Carbonell, E., Saladié, P., 2019. Neanderthal logistic mobility during MIS3: Zooarchaeological perspective of Abric Romaní level P (Spain). Quaternary Science Review, 225, 1-31. https://doi.org/10.1016/j.quascirev.2019.106033.

Martínez-Moreno, J., Torcal, R. M., Sunyer, M. R., Benito-Calvo, A., 2016. From site formation processes to human behaviour: towards a constructive approach to depict palimpsests in Roca dels Bous. Quaternary International, 417, 82-93. https://doi.org/10.1016/j.quaint.2015.09.038.

Mellars, P., 1996. The Neanderthal legacy: an archaeological perspective from Western Europe. Princeton University Press.

Moreau, G., Locht, J.-L., 2017. Importance de l'utilisation du Système d'Information Géographique pour les vastes sites de plein air du Paléolithique moyen en France septentrionale. L'exemple de Caours (Somme, France) et Beauvais (Oise, France). Archéo numériques, 1 (1), 1-12. https://doi.org/10.21494/iste.op.2017.0170.

Moroni, A., Parenti, F., Araujo, A., Boschian, G., Boschin, F., Capecchi, G., Crezzini, J., Hublin, J.J., Marciani, G., Spagnolo, V., Talamo, S., Gambogi, P., 2015. Monte Argentario (GR). Grotta di Cala dei Santi (Concessione di Scavo). Notiziario della Soprintendenza per i Beni Archeologici della Toscana, 10/2014, 364-366.

Moroni, A., Boschian, G., Crezzini, J., Montanari-Canini, G., Marciani, G., Capecchi, G., Arrighi, S., Aureli, D., Berto, C., Freguglia, M., Araujo, A., Scaramucci, S., Hublin, J.J., Lauer, T., Benazzi, S., Parenti, F., Bonato, M., Ricci, S., Talamo, S., Segre, A. G., Boschin, F., Spagnolo, V., 2019. Late Neandertals in Central Italy. High-resolution chronicles from Grotta dei Santi (Monte Argentario - Tuscany). Quaternary Science Reviews, 217, 130-151.

https://doi.org/10.1016/j.quascirev.2018.11.021.

Moroni, A., Spagnolo, V., Crezzini, J., Boschin, F., Benvenuti, M., Gardin, S., Cipriani, S., Arrighi, S., in press. Settlement, space organization and land-use of a small Middle Bronze Age community 
of central Italy. The case study of Gorgo del Ciliegio (Arezzo-Tuscany). Quaternary International. Vol. xxx, 1-16. https://doi.org/10.1016/j.quaint.2019.02.011.

Negre, J., Santiago, F., Salemme, M., 2019. The Underlying Spatial Structure of a Guanaco (Lama guanicoe) Bonebed Assemblage in the Fuegian Region, Subantarctic Insular Argentina. Journal of Archaeological Method and Theory, 26, 3-24. https://doi.org/10.1007/s10816-017-9357-8.

Neruda, P., 2017. GIS analysis of the spatial distribution of Middle Palaeolithic artefacts in Kůlna Cave (Czech Republic). Quaternary International, 435 A, 58-76.

https://doi.org/10.1016/j.quaint.2015.10.028.

Odell, G.H., 1980. The mechanics of use-breakage of stone tools: some testable hypotheses. Journal of Field Archaeology, 8, 197-209. https://doi.org/10.1179/009346981791505120.

Olsen, S.L., Shipman, P., 1988. Surface modification on bone: trampling versus butchery. Journal of Archaeological Science, 15, 535-553. https://doi.org/10.1016/0305-4403(88)90081-7.

Oron, M., Goren-Inbar, N., 2014. Mousterian intra-site spatial patterning at Quneitra, Golan heights. Quaternary International, 331, 186-202. https://doi.org/10.1016/j.quaint.2013.04.013.

Ortiz Nieto-Márquez, I., Baena Preysler, J., 2017. Did stones speak about people? Flint catchment and Neanderthal behavior from Area 3 (Cañaveral, Madrid-Spain). Quaternary International, 435 A, 144-163. https://doi.org/10.1016/j.quaint.2016.01.019.

Outram, A. K., 2002. Bone fracture and within-bone nutrients: an experimentally based method for investigating levels of marrow extraction. In: Miracle, P., Milner, N. (eds.), Consuming Passions and Patterns of Consumption. Cambridge: McDonald Institute for Archaeological Research, pp. 5164.

Pandolfi, L., Boscato, P., Crezzini J., Gatta, M., Moroni, A., Rolfo, M., Tagliacozzo, A., 2017. Late Pleistocene last occurrences of the narrow-nosed rhinoceros Stephanorhinus hemitoechus (Mammalia, Perissodactyla) in Italy. Rivista italiana di paleontologia e Stratigrafia (Research in Paleontology and Stratigraphy), 123 (2), 177-192.

Pardo, J.F.J., Tortosa, J.E.A., Aristu, B.A., Álvarez-Fernández, E., García-Pérez, A., Maestro, A., 2016. Breaking the waves: Human use of marine bivalves in a microtidal range coast during the Upper Pleistocene and the Early Holocene, Vestíbulo chamber, Nerja Cave (Málaga, southern Spain). Quaternary International, 407, 59-79. https://doi.org/10.1016/j.quaint.2015.12.089. 
Peresani M., Vanhaeren M., Quaggiotto E., Queffelec A., d'Errico, F., 2013. An ochered fossil marine shell from the Mousterian of Fumane Cave, Italy. PLoS ONE 8(7): e68572.

https://doi.org/10.1371/journal.pone.0068572.

Plavšić, S., 2015. Spatial Distribution Analysis of Burnt Artifacts and Combustion Areas in Layer 3 of Velika Balanica Cave [Анализа просторне дистрибуције горелих артефаката и зона горења у слоју 3 Велике Баланице]. Journal of the Serbian Archaeological Society 31, 7-37.

Potts R., Shipman P., Ingall E., 1988. Taphonomy, paleoecology and hominids of Lainyamok, Kenya. Journal of Human Evolution, 17 (6), 597-614. https://doi.org/10.1016/0047-2484(88)90087$\underline{5}$.

Rasic, J.T., 2004. Debitage Taphonomy. In: Hall, C. T., Larson M. L. (Eds.), Aggregate analysis in chipped stone. University of Utah Press, Salt Lake City, pp. 112-135.

Real, C., Eixea, A., Sanchis, A., Morales, J. V., Klasen, N., Zilhão, J., Villaverde, V. 2018. Abrigo de la Quebrada Level IV (Valencia, Spain): Interpreting a Middle Palaeolithic Palimpsest from a Zooarchaeological and Lithic Perspective. Journal of Paleolithic Archaeology, 1-38.

https://doi.org/10.1007/s41982-018-0012-z.

Riel-Salvatore, J., Ludeke, I.C., Negrino, F., Holt B.M., 2013. A spatial analysis of the late mousterian levels of Riparo Bombrini (Balzi Rossi, Italy). Canadian Journal of Archaeology, 37, 70-92.Ripley, B.D., 1976. The second-order analysis of stationary point processes. Journal of Applied Probability, 13 (2), 255-266. https://doi.org/10.2307/3212829.

Ripley, B.D., 1977. Modelling spatial patterns. Journal of the Royal Statistical Society, Series B, 39 (2), 172-212.

Romagnoli, F., Vaquero, M., 2016. Quantitative stone tools intra-site point and orientation patterns of a Middle Palaeolithic living floor: a GIS multi-scalar spatial and temporal approach. Quartar, 63, 47-60. https://doi.org/10.7485/QU63 3.

Romagnoli, F., Martini, F., Sarti, L., 2015. Neanderthal use of Callista chione shells as raw material for retouched tools in south-east Italy. Analysis of Grotta del Cavallo Layer L assemblage by a new methodology. Journal of Archaeological Method and Theory, 22, 1007-1037.

https://doi.org/10.1007/s10816-014-9215-x.

Romagnoli, F., Baena, J., Sarti, L., 2016. Neanderthal retouched shell tool and Quina economic and technical strategies: an integrated behaviour. Quaternary International 407 (B), 29-44.

https://doi.org/10.1016/j.quaint.2015.07.034. 
Romagnoli, F., Baena, J., Pardo Naranjo, A.I., Sarti, L., 2017. Evaluating the performance of the cutting edge of Neanderthal shell tools: a new experimental approach. Use, mode of operation, and strength of Callista chione from a behavioural, Quina perspective. Quaternary International, 427, 216-228. https://doi.org/10.1016/j.quaint.2015.11.021.

Romagnoli, F., Nishiaki, Y., Rivals, F., Vaquero, M., 2018. Time uncertainty, site formation processes, and human behaviours: New insights on old issues in High-Resolution Archaeology. Quaternary International, 474 B, 99-102. https://doi.org/10.1016/j.quaint.2018.04.033.

Roper, T. J., Tait, A. I., Fee, D., Christian, S.F., 1991. Internal structure and contents of three badger (Meles meles) setts. Journal of Zoology, 225, 115-124. https://doi.org/10.1111/j.14697998.1991.tb03805.x.

Rosell, J., Blasco, J.R., Fernandez-Lazo, C., Vaquero, M., Carbonell I Roura, E., 2012. Connecting areas: faunal refits as a diagnostic element to identify synchronicity in the Abric Romaní archaeological assemblages. Quaternary International, 252, 56-67.

https://doi.org/10.1016/j.quaint.2011.02.019.

Rosell, J., Blasco, R., Arilla, M., Fernández-Jalvo, Y., 2019. Very human bears: Wild brown bear neo-taphonomic signature and its equifinality problems in archaeological contexts. Quaternary International, 517, 67-78. https://doi.org/10.1016/j.quaint.2019.05.013.

Ruiter, D.J., Berger, L.R., 2000. Leopards as taphonomic agents in Dolomitic Caves. Implications for bone accumulations in the Hominid-bearing deposits of South Africa. Journal of Archaeological Science, 27, 665-684. https://doi.org/10·1006/jasc.1999.0470.

Rusch, L., Gregoire, S., Pois, V., Moigne, A.M., 2019. Neanderthal and carnivore occupations in unit II from the Upper Pleistocene site of Ramandils Cave,(Port-la-Nouvelle, Aude, France). Journal of Archaeological Science: Reports, 28, 1-21. https://doi.org/10.1016/j.jasrep.2019.102038. Saladié, P., Fernández, P., Rodríguez-Hidalgo, A., Huguet, R., Pineda, A., Cáceres, I., Marín, J., Vallverdú, J., Carbonell, E., 2017. The TD6. 3 faunal assemblage of the Gran Dolina site (Atapuerca, Spain): a late Early Pleistocene hyena den. Historical Biology, 1-19. https://doi.org/10.1080/08912963.2017.1384476.

Sánchez-Romero, L., Benito-Calvo, A., Pérez-González, A., Santonja, M., 2016. Assessment of Accumulation Processes at the Middle Pleistocene Site of Ambrona (Soria, Spain). Density and Orientation Patterns in Spatial Datasets Derived from Excavations Conducted from the 1960s to the Present. PloS one, 11(12), e0167595. https://doi.org/10.1371/journal.pone.0167595. 
Sanchis, A., Real, C., Sauqué, V., Núñez-Lahuerta, C., Égüez, N., Tormo, C., Pérez Ripoll, M., Carrión Marco, Y., Duarte, E., de la Rasilla, M., 2019. Neanderthal and carnivore activities at Llonin Cave, Asturias, northern Iberian Peninsula: Faunal study of Mousterian levels (MIS 3). Comptes Rendus Palevol, 18 (1), 113-141. https://doi.org/10.1016/j.crpv.2018.06.001.

Sano, K., Arrighi, S., Stani, C., Aureli, D., Boschin, F., Fiore, I., Spagnolo, V., Ricci, S., Crezzini, J., Boscato, P., Gala, M., Tagliacozzo, A., Birarda, G., Vaccari, L., Ronchitelli, A., Moroni, A., Benazzi, S., 2019. The earliest evidence for mechanically delivered projectile weapons in Europe. Nature Ecology \& Evolution 3 (10), 1409-1414. https://doi.org/10.1038/s41559-019-0990-3.

Santhanam, R., 2018a. Biology and ecology of edible marine gastropod molluscs. Apple Academic Press. NJ, USA, 2017; 435.

Santhanam, R., 2018b. Biology and ecology of edible marine bivalve molluscs. Apple Academic Press. Oakville/Waretown; 460.

Sauqué, V., Sanchis, A., 2017. Leopards as taphonomic agents in the Iberian Pleistocene, the case of Racó del Duc (Valencia, Spain). Palaeogeography, Palaeoclimatology, Palaeoecology, 472, 6782. https://doi.org/10.1016/j.palaeo.2017.01.016.

Scaramucci, S., 2018. Reperimento e diffusione delle rocce utili alla scheggiatura durante la preistoria della Toscana meridionale: il sito di La Pietra nel suo contesto. Ph.D. Dissertation. Università degli Studi di Siena, Italy.

Schick, K.D., 1986. Stone Age Sites in the Making. Experiments in the formation and transformation of archaeological occurrences. BAR International Series, vol. 319.

Schick, K.D., 1987. Experimentally-derived criteria for assessing hydrological disturbance of archaeological sites. In: Nash, D.T. Petraglia, M.D. (Eds.), Natural formation processes and the archaeological record. BAR International Series, vol. 352, pp. 86-107.

Schiffer, M.B., 1972. Archaeological context and systemic context. American Antiquity, 37, 156165. http://dx.doi.org/10.2307/278203.

Segre, A.G., 1959. Giacimenti pleistocenici con fauna e industria litica a Monte Argentario (Grosseto). Rivista di Scienze Preistoriche, XIV, 1-18.

Shennan, S., 1997. Quantifying Archaeology. Edinburgh University Press, Edinburgh. Spagnolo, V., 2017. Studio delle strategie insediative del Paleolitico Medio in Italia centromeridionale. Ph.D. Dissertation. Università degli Studi di Siena, Italy. 
Spagnolo, V., Marciani, G., Aureli, D., Berna, F., Boscato, P., Ranaldo, F., Ronchitelli, A., $2016 a$. Between hearths and volcanic ash: The SU 13 palimpsest of the Oscurusciuto rock shelter (GinosaSouthern Italy): Analytical and interpretative questions. Quaternary International, 417, 105-121. http://dx.doi.org/10.1016/j.quaint.2015.11.046.

Spagnolo, V., Boschian, G., Araujo, A., Boschin, F., Capecchi, G., Crezzini, J., Hublin, J. J., Marciani, G., Montanari-Canini, G., Parenti, F., Talamo, S., Moroni, A., 2016b. Monte Argentario (GR). Cala dei Santi: Grotta dei Santi (concessione di scavo). Notiziario della Soprintendenza per i Beni Archeologici della Toscana, 11/2015, 555-558.

Spagnolo, V., Marciani, G., Aureli, D., Berna, F., Toniello, G., Astudillo, F. J., Boschin, F., Boscato, P., Ronchitelli, A., 2019. Neanderthal activity and resting areas from Stratigraphic Unit 13 at the Middle Palaeolithic site of Oscurusciuto (Ginosa - Taranto, Southern Italy). Quaternary Science Reviews, 217, 169-193. https://doi.org/10.1016/j.quascirev.2018.06.024.

Spagnolo, V., Marciani, G., Aureli, D., Martini, I., Boscato, P., Boschin, F., Ronchitelli, A., Accepted. Climbing the time to see Neanderthal behaviour's continuity and discontinuity. SU 11 of the Oscurusciuto Rockshelter (Ginosa - Southern Italy). Archaeological and Anthropological Sciences. https://doi.org/10.1007/s12520-019-00971-9.

Speth, J.D., Meignen, L., Bar-Yosef, O., Goldberg, P., 2012. Spatial organization of middle Paleolithic occupation X in Kebara cave (Israel): concentrations of animal bones. Quaternary International, 247, 85-102. https://doi.org/10.1016/j.quaint.2011.03.001.

Stevenson, M.G., 1985. The Formation of Artifact Assemblages at Workshop/Habitation Sites: Models from Peace Point in Northern Alberta. American Antiquity, 50, 63-81.

http://dx.doi.org/10.2307/280634.

Stevenson, M.G., 1991. Beyond the formation of hearth-associated artifact assemblages. In: Kroll, E.M., Douglas Price, T. (Eds.), The Interpretation of Archaeological Spatial Patterning. Springer, New York-London, pp. 269-299.

Stiner. M.C., 1994. Honor Among Thieves: a Zooarchaeological Study of Neandertal Ecology. NJ. Princeton University Press, Princeton.

Stringer. C.B., Finlayson. J.C., Barton. R.N., Fernández-Jalvo. Y., Cáceres. I., Sabin. R.C., Rhodes. E.J., Currant. A.P., Rodríguez-Vidal. J., Giles-Pacheco. F., Riquelme Cantal. J.A., 2008. Neanderthal exploitation of marine mammals in Gibraltar. PNAS 105 (38), 14319-14324. https://doi.org/10.1073/pnas.0805474105. 
Thacher D., Milne S.B., Park R., 2017. Applying GIS and statistical analysis to assess the correlation of human behaviour and ephemeral architectural features among Palaeo-Eskimo sites on Southern Baffin Island, Nunavut. Journal of Archaeological Science: Reports, 14, 21-30. https://doi.org/10.1016/j.jasrep.2017.05.004.

Tringham, R., Cooper, G., Odell, G., Voytek, B., Whitman, A., 1974. Experimentation in the formation of edge damage: a new approach to lithic analysis. Journal of Field Archaeology, 1, 171196. https://doi.org/10.1179/jfa.1974.1.1-2.171.

Valensi, P., Michel, V., El Guennouni, K., Liouville, M., 2013. New data on human behavior from a 160,000 year old Acheulean occupation level at Lazaret cave, south-east France: an archaeozoological approach. Quaternary International, 316, 123-139.

https://doi.org/10.1016/j.quaint.2013.10.034.

Van Gijn, A., 2010. Flint in Focus. Lithic Biographies in the Neolithic and Bronze Age. Sidestone press, Leiden.

Vaquero, M., 2008. The history of stones: behavioural inferences and temporal resolution of an archaeological assemblage from the Middle Palaeolithic. Journal of Archaeological Science, 35, 3178-3185. https://doi.org/10.1016/j.jas.2008.07.006.

Vaquero, M., Chacón, M.G., Cuartero, F., García-Antón, M.D., Gómez de Soler, B., Martínez, K., 2012. Time and space in the formation of lithic assemblages: The example of Abric Romaní Level J. Quaternary International, 247, 162-181. http://dx.doi.org/10.1016/j.quaint.2010.12.015.

Vaquero, M., Fernández-Laso, M., Chacón, M.G., Romagnoli, F., Rosell, J., Sañudo, P., 2017. Moving things: comparing lithic and bone refits from a Middle Paleolithic site. Journal of Anthropological Archaeology, 48, 262-280. https://doi.org/10.1016/j.jaa.2017.09.001.

Villaverde, V., Eixea, A., Zilhão, J., Sanchis, A., Real, C., Bergadà, M., 2017. Diachronic variation in the Middle Paleolithic settlement of Abrigo de la Quebrada (Chelva, Spain). Quaternary International, $435 \mathrm{~A}, 164-179$. https://doi.org/10.1016/j.quaint.2015.09.075.

Voorhies, M.R., 1969. Taphonomy and population dynamics of an Early Pliocene vertebrate fauna, Knox County, Nebraska. Contributions to Geology. Special Paper No. 1. University of Wyoming Press, Wyoming.

Way, A.M., 2018. A behavioral approach to cumulative palimpsests: An example from Weereewaa (Lake George), Australia. Journal of Anthropological Archaeology, 52, 59-70.

https://doi.org/10.1016/j.jaa.2018.09.005. 
Waelbroeck, C., Labeyrie, L., Michel, E., Duplessy, J.C., Lambeck, K., Mcmunus, J.F., Balbon, E., Labracherie, M., 2002. Sea-level and deep water temperature changes derived from benthic foraminifera isotopic records. Quat. Sci. Rev. 21, 295-305. https://doi.org/10.1016/S02773791(01)00101-9.

Whallon, R., 1984. Unconstrained clustering for the analysis of spatial distributions in archaeology. In: Hietala, H.J. (Ed.), Intrasite Spatial Analysis in Archaeology. Cambridge University Press, Cambridge, pp. 242-277.

Wierer, U., Arrighi, S., Bertola, S., Kaufmann, G., Baumgarten, B., Pedrotti, A., Pernter, P., Pelegrin, J., 2018. The Iceman's lithic toolkit: Raw material, technology, typology and use. PLoS ONE, 13 (6), e0198292. https://doi.org/10.1371/journal.pone.0198292.

Zilhão J., Angelucci D.E., Badal-García E., d'Errico F., Daniel F., Dayet L., Douka K., Higham T.F.G., Martínez-Sánchez M.J., Montes-Bernárdez R., Murcia-Mascarós S., Pérez-Sirvent C., Roldán-García C., Vanhaeren M., Villaverde, V., Wood R., Zapata J., 2010. Symbolic use of marine shells and mineral pigments by Iberian Neandertals. PNAS 107 (3) 1023-1028. https://doi.org/10.1073/pnas.0914088107. 